\title{
Comparative Proteomics Reveals Set of Oxidative Stress and Thaumatin-Like Proteins Associated with Resistance to Late Blight of Tomato
}

\author{
Bruno Soares Laurindo ${ }^{*}$, Renata Dias Freitas Laurindo1, Patrícia Pereira Fontes², \\ Camilo Elber Vital ${ }^{3}$, Fábio Teixeira Delazari' ${ }^{1}$, Maria Cristina Baracat-Pereira ${ }^{2}$, \\ Derly José Henriques da Silva ${ }^{1}$
}

${ }^{1}$ Department of Phytotechny, Federal University of Viçosa, Viçosa, Minas Gerais, Brazil ${ }^{2}$ Department of Biochemistry and Molecular Biology, Federal University of Viçosa, Viçosa, Minas Gerais, Brazil ${ }^{3}$ Biomolecules Analysis Cente, Federal University of Viçosa, Viçosa, Minas Gerais, Brazil Email: ^brunosoareslaurindo@gmail.com

How to cite this paper: Laurindo, B.S., Laurindo, R.D.F., Fontes, P.P., Vital, C.E., Delazari, F.T., Baracat-Pereira, M.C. and da Silva, D.J.H. (2018) Comparative Proteomics Reveals Set of Oxidative Stress and Thaumatin-Like Proteins Associated with Resistance to Late Blight of Tomato. American Journal of Plant Sciences, 9, 789-816. https://doi.org/10.4236/ajps.2018.94062

Received: February 9, 2018

Accepted: March 17, 2018

Published: March 20, 2018

Copyright $\odot 2018$ by authors and Scientific Research Publishing Inc. This work is licensed under the Creative Commons Attribution International License (CC BY 4.0).

http://creativecommons.org/licenses/by/4.0/

\begin{abstract}
Proteomics techniques were used to study the molecular mechanisms involved in the defense of tomato against late blight (Phytophthora infestans). Proteins were extracted from resistant access BGH-2127 and susceptible cultivar "Santa Clara". Leaves of the inoculated and non-inoculated (control) genotypes were collected at 0,2 , and $48 \mathrm{~h}$ after inoculation and analyzed by two-dimensional electrophoresis (2-DE), followed by identification with mass spectrometry (MALDI TOF-TOF). A total of 56 differentially abundant proteins were identified, of which 39 were resistant genotypes and 17 were susceptible. These proteins were categorized into functional groups of energy and metabolism, photosynthesis, stress and defense, transcription, other proteins, and as un-characterized ones. For access BGH-2127, oxidative stress proteins (2-cis peroxiedoxin BAS1 and 2-cis peroxiredoxin) and thaumatin-like protein showed increase in the relative abundance at 0 and $48 \mathrm{~h}$ of inoculation, respectively, and were therefore considered important for the defense mechanism of this genotype. The expression standards evaluated by real-time PCR differed from the results of the proteomic analysis. The protein-protein interaction networks provided important information on the cellular activities involved in the resistance of BGH-2127 late blight.
\end{abstract}

\section{Keywords}

Solanum lycopersicum L., Pathogenesis-Related (PR) Proteins, Resistance to Phytophthora infestans 


\section{Introduction}

The oomycete Phytophthora infestans (Mont.) De Bary, the etiological agent of late blight is one of the most destructive pathogens of tomato (Solanum lycopersicum L.), which is responsible for the economic losses of tomato crops [1].

Despite its importance, most of the tomato cultivars available in the market are susceptible to late blight, and the disease management is carried out mainly through fungicide application [2], which is an onerous practice that can cause further damage to the environment and contribute to the selection of resistant isolates [3].

As an alternative, the development and use of genetically resistant cultivars represent satisfactory strategies from the social, economic, and environmental point of view for the control of late blight [4]. In this context, the transfer of resistance genes listed under tomato accesses in Gene Banks appears to be a suitable alternative, especially for the same species that are to be improved, since it facilitates crosses for gene transfer [5] and faster recovery of the desired agronomic characteristics [6].

The access BGH-2127 conserved in the Gene Bank of the Federal University of Vicosa, Brazil used in this study belonged to the cultivated species Solanum lycopersicum and was highlighted for its resistant to late blight [7]. The differential characteristic of this species genotype enables its potential use in breeding programs to avoid the occurrence of common issues due to genetic drag when wild parents are crossed.

Plants have mechanisms of highly efficient defenses, such as induced response triggered by the perception of the phytopathogenic agent [8]. This mechanism of defense includes hypersensitivity response and the production of reactive oxygen species, phytoalexins, and pathogenesis-related proteins (PR) [9]. The PR are classified into 17 families according to their properties and mechanisms of action, which include the families PR-5 (thaumatin-like family) that possess activity against the attack of oomycetes and PR-9 (peroxidases), which are important in initiating rapid responses against the attack of pathogens [10].

Thus, studies that allow for the better understanding of the molecular basis of tomato interaction versus late blight are necessary. Genes and proteins related to plant defense during the infection process have been identified through molecular biology strategies [11] [12] [13]. In this context, the methodology of proteomic analysis becomes a viable alternative, providing information and tools for the better understanding of the plant-pathogen relationship and for obtaining resistant cultivars. Proteomics offers the possibility of simultaneously studying the set of proteins present in a biological unit, its abundance, genotype-dependent variations, response to environmental changes, post-translational modifications, or interactions with other molecular entities [14]. In tomato culture, proteomic analysis has been successfully applied to identify proteins in different pathosystems [15] [16] [17].

Thus, the objective of this study was to identify proteins related to resistance 
against late blight using proteomic tools for tomato genotypes that may explain the possible molecular mechanisms of resistance to this disease.

\section{Material and Methods}

\subsection{Plant Genetic Resources and Experiments}

The experiment was conducted at the Federal University of Viçosa (UFV) in Viçosa, Minas Gerais, Brazil (2045'14"S, 4252'53"W, $648.74 \mathrm{~m}$ ). The resistant genotype BGH-2127 access [7], conserved in the Gene Bank of Federal University of Viçosa, Minas Gerais State, Brazil, and susceptible cultivar Santa Clara [5], both belonging to the $S$. lycopersicum species, were evaluated. The plants were grown in a greenhouse in a completely randomized design with three replicates per genotype. Each replicate consisted of one set of three plants. Each plant was grown in one vessel of 10-L volume for soil.

\subsection{Pathogen Inoculation and Sample Collection for Molecular Analyses}

The collection, preparation, and inoculation of isolates of $P$. infestans was performed according to a methodology proposed elsewhere [5]. After 45 days of transplanting, the plants were inoculated with a mixture of sporangia from $P$. infestans isolates, which are pathogenic to tomato, collected in fields of production of tomato from different cities of Minas Gerais State, Brazil, including Cajuri, Coimbra, Ervália and Viçosa. For inoculum multiplication, infected leaflets were kept in plastic trays previously lined with paper towels moistened in distilled water and kept at $18^{\circ} \mathrm{C}$ for $48 \mathrm{~h}$. Subsequently, a sporangium suspension was prepared for each isolate, and the hemacytometer concentration was adjusted to $1 \times 10^{3} \mathrm{~mL}^{-1}$ of sporangia. The inoculation was performed by spraying $10-\mathrm{mL}$ of suspension per plant by using the manual costal spray. A day after the inoculation, in order to guarantee high humidity to the environment, the plants were irrigated by micro-sprinkler.

Leaf sampling times were established based on the search for rapid plant responses and the time required for the pathogen to penetrate and colonize the plant tissues [18]. After the inoculation of each plant, the leaves were collected at every 0,2 , and $48 \mathrm{~h}$; the leaves of uninoculated (control) genotype were also collected at the same time. Time 0 (zero) corresponds to the collection of leaves immediately after inoculation. Soon after the collections, the leaves were frozen under liquid nitrogen $\left(\right.$ at $-80^{\circ} \mathrm{C}$ ) until requirement for the preparation of plant extracts for molecular analysis.

\subsection{Proteomic Analysis}

\subsubsection{Extraction and Quantification of Proteins}

The extraction procedure was followed as described in a previous study [19], albeit with some modifications. Briefly, tomato leaves ( $5 \mathrm{~g}$ ) of each genotype were individually grounded in liquid nitrogen using mortar and pestle. The obtained 
powder was homogenized with $2 \%$ polyvinylpolypyrrolidone (PVPP) and added to $1: 4$ extraction buffer (sample:solution, w:v), containing $40 \mathrm{mM}$ of Tris- $\mathrm{HCl}$ $(\mathrm{pH}$ 7.5), $250 \mathrm{mM}$ sucrose, $10 \mathrm{mM}(\mathrm{w} / \mathrm{v})$ ethylenediaminetetraacetic acid (EDTA), $1 \mathrm{mM}$ of $1 \%$ Triton X-100, $1 \mathrm{mM}$ phenylmethylsulfonyl fluoride (PMSF), $2 \mathrm{mM}$ thiourea, $1 \mathrm{mM}$ benzamidine, and $1 \mathrm{mM}$ dithiothreitol (DTT). After stirring for $2 \mathrm{~h}$ at $4^{\circ} \mathrm{C}$, the material was centrifuged at 20,100 $\times \mathrm{g}$ for $30 \mathrm{~min}$ at $4^{\circ} \mathrm{C}$. The supernatant was reserved (supernatant 1 ). The extraction buffer was added to the precipitate again in the ratio 1:4 (sample:solution, w:v). After $1 \mathrm{~h}$ and $15 \mathrm{~min}$ of stirring at $4^{\circ} \mathrm{C}$, the material was re-centrifuged at $20,100 \times \mathrm{g}$ for 30 $\min$ at $4^{\circ} \mathrm{C}$. The obtained supernatant was recovered (supernatant 2 ) and mixed with the previously reserved (supernatant 1 ) to form a soluble protein extract.

The solution was then left to precipitate overnight at $-20^{\circ} \mathrm{C}$ with the addition of $10 \%$ trichloroacetic acid in ice-cold acetone and $1 \mathrm{mM}$ DTT in a ratio of 1:1.5 (sample:solution, v:v). Each sample was then centrifuged at 20,100 $\times \mathrm{g}$ for $30 \mathrm{~min}$ at $4^{\circ} \mathrm{C}$ and the supernatant was discarded. The precipitate was washed four times with ice-cold acetone and once with $80 \%(\mathrm{v} / \mathrm{v})$ ethanol and $1 \mathrm{mM} \mathrm{DTT}$, followed by drying at the room temperature in a SpeedVac system (Savant SpeedVac, Thermo Scientific, USA).

The obtained protein pellet was solubilized in $600 \mu \mathrm{L}$ of solubilization buffer (7M urea, 2 Mthiourea, 2\% 3-[(3-Cholamidopropyl)dimethylammonio]-1propanesulfonate (CHAPS), and $0.3 \%$ DTT), with the help of a bath sonicator. The supernatant was removed and quantified by the method given elsewhere [20] using bovine serum albumin (BSA) as the standard protein.

\subsubsection{Two-Dimensional Electrophoresis (2-DE)}

The isoelectric focusing (IEF) of the proteins was performed using a 24-cm strip containing an immobilized $\mathrm{pH}$ gradient (IPG) ranging from 3 to 10 on an EttanIPGphor 3 equipment [21]. A sample containing $1200 \mu \mathrm{g}$ of protein was added to the rehydration buffer consisting of $40 \mathrm{mM}$ DTT, IPG buffer (pH3-10, and DeStreak commercial reagent [21] in a total volume of $450 \mu \mathrm{L}$. The strips were focused under a controlled temperature of $20^{\circ} \mathrm{C}$, according to the following steps: 1) 200 V.h single step for $2 \mathrm{~h}$; 2) 500 V.h in a single step of 500 volts; 3) 800 V.h in a gradient up to 1000 volts; 4) 16,500 V.h in a gradient up to 10,000 volts; and 5) 27,500 V.h in a single step of 10,000 volts. The maximum amperage was $50 \mu \mathrm{A}$ per strip. After focusing, the tapes were immediately stored at $-80^{\circ} \mathrm{C}$ until use for second-degree mass separation.

The proteins were reduced by equilibrating the IPG strip for $15 \mathrm{~min}$ in a DTT buffer (6 M urea, 25.5\% (v/v) glycerol, $2 \%$ sodium dodecyl sulfate (SDS), 1\% DTT, $0.002 \%$ bromophenol, and $75 \mathrm{mM}$ Tris- $\mathrm{HCl}, \mathrm{pH} 8.8$ ). Then, the proteins were alkylated in a buffer similar to the DTT buffer, except that it contained $2.5 \%$ iodoacetamide, for $15 \mathrm{~min}$. The strips were placed on top of the SDS-gel and fixed with agarose solution $(0.5 \%$ agarose, $0.002 \%$ bromophenol blue, 25 $\mathrm{mM}, 192 \mathrm{mM}$ Glycine, and 1\% SDS).

The second dimension was performed on $12.5 \%$ SDS-PAGE in a DaltSix 
cube-type [21], as described elsewhere [22]. Electrophoresis was initially performed with $10 \mathrm{~mA}$ per gel and $80 \mathrm{~V}$ voltage for $45 \mathrm{~min}$, followed by the use of $40 \mathrm{~mA}$ current per gel and a voltage of $500 \mathrm{~V}$ until the bromophenol blue reached the lower limit of the gel. The temperature was maintained at $8^{\circ} \mathrm{C}$ by using thermostatic circulator cooling. Three gels were obtained by treatment, corresponding to three biological replicates.

At the end of the second dimension, the proteins were fixed in a solution containing $10 \%(\mathrm{v} / \mathrm{v})$ phosphoric acid and 40\% (v/v) ethanol for $12 \mathrm{~h}$, followed by development for $72 \mathrm{~h}$ in a solution containing $8 \%$ ammonium sulfate $(\mathrm{m} / \mathrm{v})$, 0.08\% Coomassie Blue G-250, and 20\% (v/v) ethanol. The gels were stored in a solution containing $5 \%(\mathrm{v} / \mathrm{v})$ acetic acid.

\subsubsection{Acquisition and Analysis of 2-DE Gel Images}

The gels were scanned by using the Image Scanner III [21]. The images were analyzed with Image Master 2D Platinum 7.0 software [20]. With the help of this software, the volume (area $\times$ intensity) of each spot present in the gel was obtained, which is proportional to the abundance of the protein in the different conditions. The software also made it possible to identify the corresponding spots in the different conditions (match), allowing a comparison between them. The expression values were considered significant according to the analysis of variance (ANOVA) at $p<0.05$. Proteins in which the abundance ranged at least 1.5 times were considered to be differentially abundant.

\subsection{Sample Trypsinization}

Trypsinization was performed according to the method described earlier [23], with the following modifications. Initially, differentially abundant spots were removed from the gels. For dye removal, pieces of gel containing the proteins were transferred to $500 \mu \mathrm{L}$ tubes containing $50 \%$ acetonitrile solution in $25 \mathrm{mM}$ (v/v) ammonium bicarbonate solution for the first wash (one time) for $12 \mathrm{~h}$. Then, a second wash in the same solution was performed for $1 \mathrm{~h}$ and another wash with $50 \%$ methanol in $25 \mathrm{mM}$ (v/v) ammonium bicarbonate solution) for another hour. The decolorization solution was removed, and the gel pieces were dehydrated with acetonitrile for $5 \mathrm{~min}$ for two-fold drying in the Speed Vac Concentrator Plus (Eppenddorf) for $10 \mathrm{~min}$. The proteins were reduced with 25 $\mathrm{mM}$ DTT in $100 \mathrm{mM}$ ammonium bicarbonate for $30 \mathrm{~min}$ at $56^{\circ} \mathrm{C}$ in a water bath and alkylated with $75 \mathrm{mM}$ iodoacetamide in $100 \mathrm{mM}$ ammonium bicarbonate for $30 \mathrm{~min}$ at the room temperature. The gel pieces were washed with $100 \mathrm{mM}$ ammonium bicarbonate for $10 \mathrm{~min}$ for two-fold drying and then dehydrated in acetonitrile for $5 \mathrm{~min}$ by drying in the SpeedVac for $10 \mathrm{~min}$.

For enzymatic digestion, the gels were rehydrated with a solution containing trypsin $(20 \mu \mathrm{g} / \mathrm{mL})$ in $40 \mathrm{mM}$ ammonium bicarbonate solution ( $\mathrm{pH} 8.0)$ and $10 \%$ acetonitrile. The enzyme solution $(15 \mu \mathrm{L}$ ) (Trypsin Gold, Mass Spectrometry grade, Promega V5280) was added cold (at $4^{\circ} \mathrm{C}$ ), and the samples were kept 
on ice for $45 \mathrm{~min}$ to penetrate the gel. The samples were added with $50 \mu \mathrm{L}$ of 40 $\mathrm{mM}$ ammonium bicarbonate solution in $10 \%$ acetonitrile and incubated at $37^{\circ} \mathrm{C}$ for $22 \mathrm{~h}$ in a water bath.

The gel pieces were sonicated for $10 \mathrm{~min}$, shaken at $1500 \mathrm{~g}$ for 2 min under ambient temperature, and the solution was placed into fresh tubes. To the remaining pieces of gel, $40 \mu \mathrm{L}$ of the solution of $5 \%$ formic acid in $50 \%(\mathrm{v} / \mathrm{v})$ acetonitrile was added in two sequential steps to recover the largest amount of tryptic fragments. They were agitated again at $1500 \mathrm{~g}$ for $2 \mathrm{~min}$ under ambient temperature and the solution was removed and added to the new tube.

After these steps, the entire solution was completely evaporated in the Speed $\mathrm{Vac}$ and the tryptic peptides were re-suspended in $2.5 \mu \mathrm{L}$ of $0.1 \%$ trifluoroacetic acid (TFA) solution. All samples were submitted to desalination on a C18 hydrophobicity column (ZipTip-Eppendorf), according to the recommendations of the manufacturer.

\subsection{Mass Spectrometry and Protein Identification}

Protein identification was performed using the MALDI-TOF/TOF Ultraflex III (BruckerDaltonics)-type mass spectrometer, available in the Nucleus of Biomolecules, UFV. About $1 \mu \mathrm{L}$ of each sample containing the peptides was applied to the steel plate of the mass spectrometer together with $\alpha$-cyano-4-hydroxy cinnamic acid matrix (Sigma) in a 1:1 ratio. The samples were analyzed in a positive mode with the reflector activated.

The standard list of proteins was obtained from the Lycopersicum Protein Database (download on 03/21/16, with 33,950 entries), Solanaceae family (download on 03/14/2016, with 114,203 entries), and the Viridiplantae group (download on 04/27/15, with 2,864,275 entries), all obtained from UNIPROT, through the use of the MASCOT application, version 2.4.0 (Matrix Science, London, UK). The parameters used for research included enzymatic digestion by trypsin with a lost cleavage, allowing a tolerance error of $0.2 \mathrm{Da}$ for the parental ion and of $0.5 \mathrm{Da}$ for the fragments, carbamidomethylation of cysteine as a fixed modification, and the oxidation of methionine as a variable modification.

Proteins identified as "Uncharacterized" by MASCOT were processed by the BLAST algorithm [24]. Through this algorithm, it was possible to identify the proteins present in the database deposited in the Phytozome, whose sequences showed a higher level of identity with the sequences of the "Uncharacterized" proteins.

The result obtained by MASCOT was validated by the SCAFFOLD application version 3.6.4 (Proteome Software Inc., Portland, OR). For validation of the identified peptides, the Peptide Prophet Algorithm was applied [25] and the Protein Prophet Algorithm [26] was used as the acceptance criterion parameters were adopted with a minimum of $90 \%$ probability of identification for both peptides and proteins, with the presence of at least one single peptide for each identified protein. 


\subsection{Bioinformatics Analysis}

The identified proteins were functionally categorized using the Mapman program [27].

Once the differentially abundant proteins for BGH-2127 and Santa Clara genotypes were listed, the construction of a protein-protein interaction network was performed using the STRING v software version 10.0 [28].

\subsection{Analysis of the Relative Expression of Proteins by Real-Time PCR}

The plant leaf samples were macerated in liquid nitrogen and total RNA was extracted with TRIZOL reagent (Invitrogen), according to the manufacturer's protocol. In approximately $100 \mathrm{mg}$ of the macerated material, $1 \mathrm{~mL}$ of the TRIZOL reagent was added and incubated for $5 \mathrm{~min}$. Subsequently, $200 \mu \mathrm{L}$ of chloroform was added to the tube and the mixture was homogenized for $3 \mathrm{~min}$. The samples were centrifuged at $12,000 \times \mathrm{g}$ for $15 \mathrm{~min}$ at $4^{\circ} \mathrm{C}$. The supernatant was transferred to a new tube, and $500 \mu \mathrm{L}$ of isopropyl alcohol was added. After $30 \mathrm{~min}$ of centrifugation at $12,000 \times \mathrm{g}$ for $10 \mathrm{~min}$ at $4^{\circ} \mathrm{C}$, the supernatant was removed and the pellet formed were washed with 75\% ethanol. Next, the pellet was centrifuged at $9500 \times \mathrm{g}$ for $5 \mathrm{~min}$ at $4^{\circ} \mathrm{C}$, excess ethanol was removed, and the pellet was re-suspended with free water from DNases and RNases. RNA was quantified SpectraMax M5 microplate/cuvette reader (Molecular Devices) and analyzed on $1.5 \%(\mathrm{w} / \mathrm{v})$ agarose gel stained with $0.1 \mu \mathrm{g} / \mathrm{mL}$ ethidium bromide.

To eliminate any contamination with genomic DNA, total RNA extracted was treated with RQ1 RNase-Free DNase (Promega). To that end, $3 \mu \mathrm{L}$ of DNase (1 $\mathrm{U} / \mu \mathrm{L}), 1 \mu \mathrm{L}$ of RQ1 RNase-Free DNase 10X Reaction Buffer, and DEPC water were added to the total RNA ( $3 \mu \mathrm{g}$ ) to complete the final volume of $10 \mu \mathrm{L}$. The samples were incubated at $37^{\circ} \mathrm{C}$ for $30 \mathrm{~min}$. The enzyme was inactivated by the addition of $1 \mu \mathrm{L}$ of RQ1 DNase Stop Solution and incubation for $10 \mathrm{~min}$ at $65^{\circ} \mathrm{C}$. For reverse transcription, $500 \mathrm{ng}$ of DNase-treated RNA was used in the reaction and $1 \mu \mathrm{L}$ of oligodT (stock at $500 \mu \mathrm{g} / \mathrm{mL}$ ) was added.

The RNA was denatured at $70^{\circ} \mathrm{C}$ for $5 \mathrm{~min}$ (followed by incubation on ice for $1 \mathrm{~min}$ ) and $4 \mu \mathrm{L}$ of $5 \times$ First-Strand Buffer, $2 \mu \mathrm{L}$ of $0.1 \mathrm{M} \mathrm{DTT}, 1 \mu \mathrm{L}$ of dNTP mix (dGTP, $1 \mu \mathrm{L}$ of $40 \mathrm{U} / \mu \mathrm{L}$ RNaseOUT Recombinant Ribonuclease Inhibitor, $1 \mu \mathrm{L}$ of the enzyme M-MLV RT (200 U/ $\mu \mathrm{L}$; Promega) and DEPC water to complete the final volume of $12 \mu \mathrm{L}$. The samples were incubated at $42^{\circ} \mathrm{C}$ for $60 \mathrm{~min}$. The obtained cDNA was quantified by the SpectraMax M5 microplate/cuvette reader (Molecular Devices).

Real-time PCR assays were conducted according to the Applied Biosystems manuals. Specific primers were designed using online software Primer 3 (http://frodo.wi.mit.edu/primer3/). The cDNA samples were diluted to a final concentration of $100 \mathrm{ng} / \mu \mathrm{L}$. Amplification of the target fragments was performed using StepOne ${ }^{\text {ts }}$ Real-Time PCR System (Applied Biosystems). The total reaction volume per sample was $10 \mu \mathrm{L}$, which was composed of specific oligo- 
nucleotides encoding the 2-cis peroxyredoxin BAS1 (FW:

5'-CCTTCTGCTTTTAATGGACTTCGT-3'; RV:

5'-TGAGCAACCCGAGTATTGATTG-3'), and thaumatin-like (FW:

5'-GCGGTGGTCGACGTCTTG-3'; RV:

5'-ACCCCATATACGTGCCATCTTAGT-3'), inoculated and uninoculated (control) BGH-2127 plant cDNAs with $P$. infestans, and the SYBR Green PCR Master Mix Kit (Applied Biosystems). The reactions were performed in duplicate on a 48-well plate. The amplification conditions followed were $95^{\circ} \mathrm{C}$ for 10 min, 40 cycles of $94^{\circ} \mathrm{C}$ for $15 \mathrm{~s}$, and $60^{\circ} \mathrm{C}$ for $1 \mathrm{~min}$. For the quantification of gene expression, the REST software was used. The primer specific actin (FW: 5'-CCTTCAACGTTCCAGCTATG-3'; RV:

5'-TCACCAGAGTCCAACACAATAC-3') [29] was used as an endogenous control for the normalization of qRT-PCR. For the quantification of gene expression, the REST software was used (https://www.qiagen.com/) [30]. Statistical differences are significant when $\mathrm{p}<0.05$ was calculated by comparing the cycle thresholds of the target gene with that of the housekeeping gene.

\section{Results}

\subsection{Analysis of the Protein Profile in Response to Late Blight Inoculation}

The two-dimensional gel proteomic analysis of tomato genotypes BGH-2127 and Santa Clara after 0, 2, and $48 \mathrm{~h}$ of inoculation with P. infestans, a total of 311 spots were detected, 94 of which were considered to be differentially $(\mathrm{p}<0.05)$. From this result, 56 spots were identified by mass spectrometry, of which 17 were associated to Santa Clara cultivar (Figure 1(a)) and 39 to BGH 2127 (Figure 1(b)). Only 6 differentially abundant spots $(19,28,122,132,188$, and 303) were common to the two genotypes, evidencing that different mechanisms are used by these genotypes against late blight.

The 17 proteins identified from the Santa Clara genotype were categorized into five functional groups, $23 \%$ were related to metabolism and energy (4 proteins), $47 \%$ to photosynthesis ( 8 proteins), $18 \%$ to stress and defense ( 3 proteins), $6 \%$ to transcription (1 protein) and $6 \%$ to non-characterized group (1 protein). Of these, 8 genotypes were down-regulated and 9 were upregulated (Table 1). An increase in the relative abundance of proteins involved in the stress and defense process and for uncharacterized protein were observed. Proteins related to metabolism and energy as well as those related to photosynthesis showed changes in their balanced abundance levels. For protein related to transcription, a reduction in the relative abundance was observed (Figure 2).

A total of six functional groups of proteins related to BGH-2127 genotype were formed, $15 \%$ of which were associated with energy and metabolism (6 proteins), $46 \%$ to photosynthesis (18 proteins), $23 \%$ to stress and defense (8 proteins), $8 \%$ to transcription ( 3 proteins), $3 \%$ to other proteins (1 protein), and $5 \%$ to non-characterized groups ( 2 proteins). Among the 39 proteins identified 


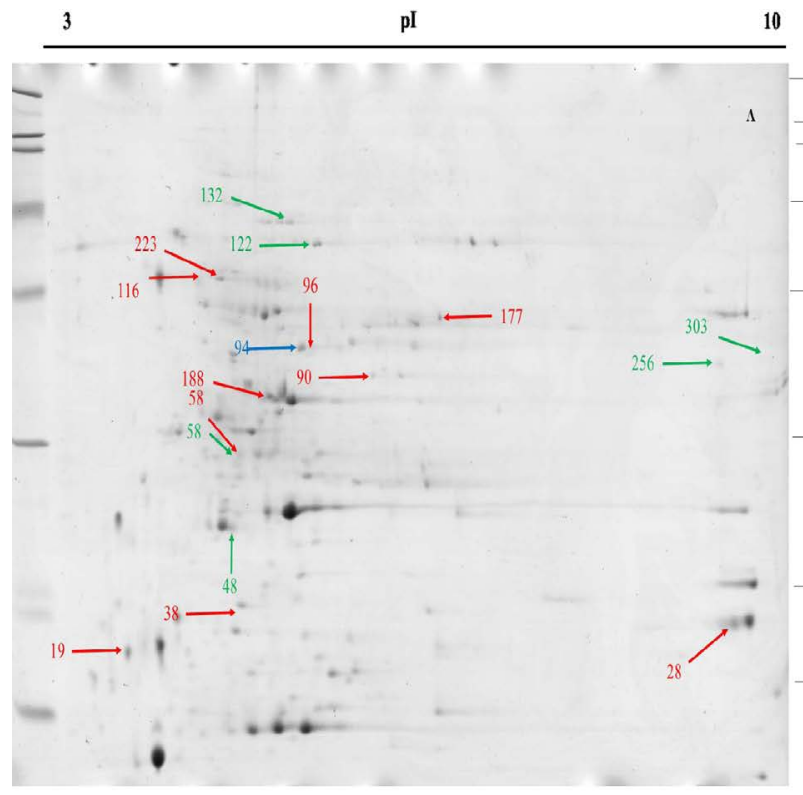

(a)

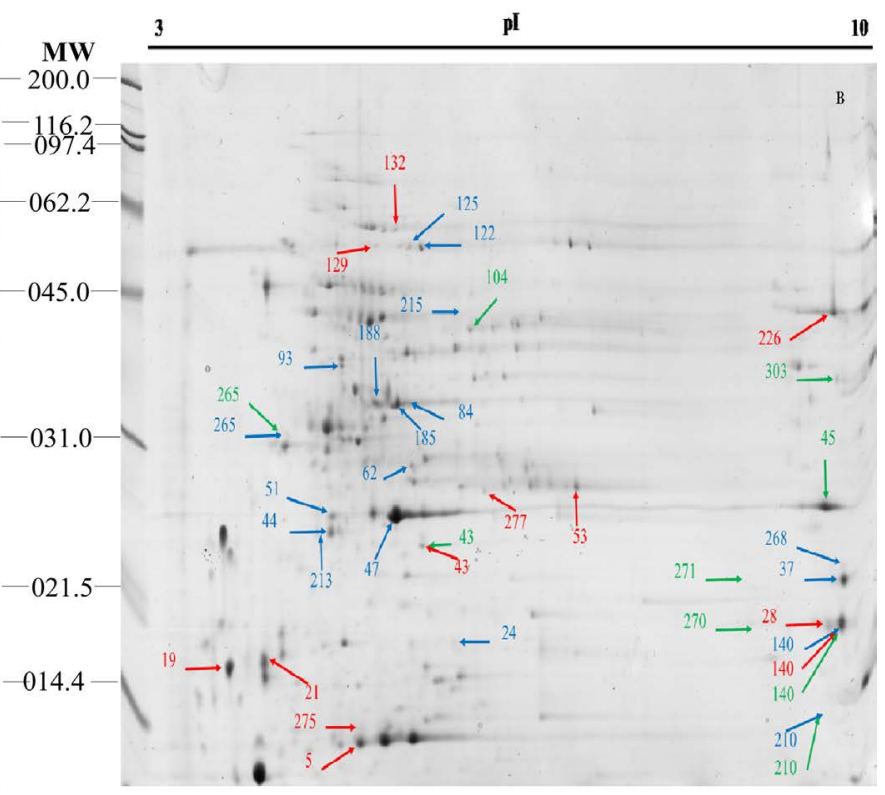

(b)

Figure 1. The two-dimensional gel representatives of tomato leaf extract in IPG pH 3 to 10 and 12.5\% SDS-PAGE in $24-\mathrm{cm}$ gel. Differentially abundant spots and their respective IDs for Santa Clara (a) and BGH-2127 (b) genotypes at 0, 2, and 48 h after inoculation with $P$. infestans are indicated by the blue, red, and green arrows, respectively. The Image Master 2D Platinum 7.0 software generated the spots numbers (IDs) automatically. The same spots present in different gels, have the same number. PI: isoelectric point; MW: molecular masses (KDa).

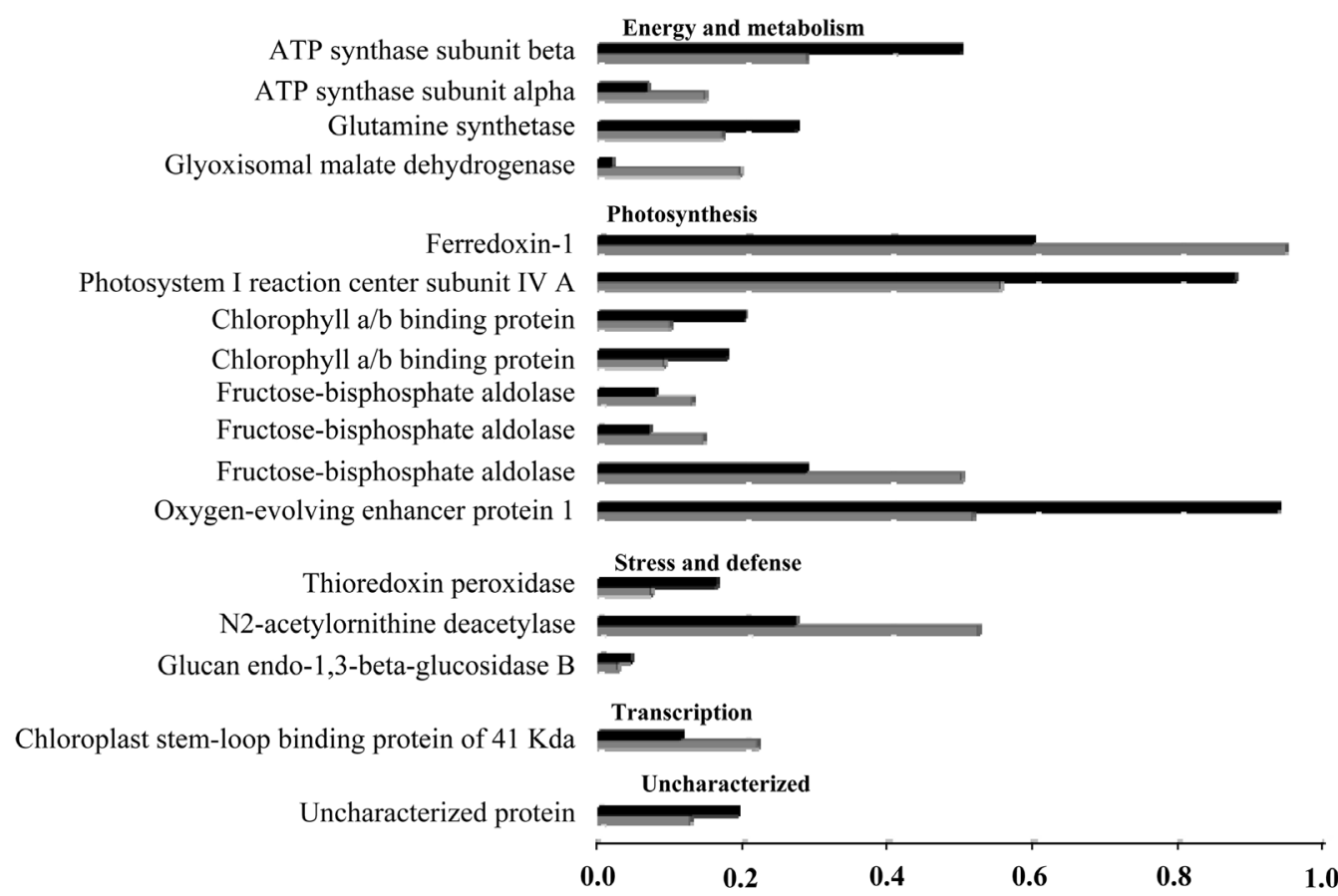

Relative abundance (\% volume)

Down-regulated

Up-regulated

Figure 2. Relative abundance (\% volume) of differentially abundant proteins considering treatments inoculated and not inoculated with P. infestans in Santa Clara genotype. 
Table 1. Differentially abundant proteins in the Santa Clara susceptible genotype after inoculation with $P$. infestans identified by mass spectrometry.

\begin{tabular}{|c|c|c|c|c|c|c|c|c|c|}
\hline $\begin{array}{l}\text { aID } \\
\text { (Time) }\end{array}$ & ${ }^{\mathrm{b}}$ Access & $\begin{array}{l}\text { Protein } \\
\text { (organism) }\end{array}$ & $\begin{array}{r}{ }^{c} \mathrm{pI} / \mathrm{N} \\
\text { Experimental }\end{array}$ & $\frac{\mathrm{IW}}{\text { Theoretical }}$ & $\begin{array}{l}{ }^{\mathrm{d}} \text { Level of } \\
\text { bundance }\end{array}$ & $\begin{array}{c}\text { Anova } \\
(\mathrm{P}< \\
0.05) \\
\end{array}$ & $\begin{array}{c}{ }^{\mathrm{e} C o v e r a g e} \\
(\%)\end{array}$ & ${ }^{\text {fScore }}$ & $\begin{array}{l}\text { gPeptides } \\
\text { identified }\end{array}$ \\
\hline \multicolumn{10}{|c|}{ Energy and metabolism } \\
\hline $122(\mathrm{~T} 48)$ & Q2MI93 & $\begin{array}{l}\text { ATP synthase subunit } \\
\text { beta } \\
\text { (Solanum lycopersicum) }\end{array}$ & $5.50 / 54.28$ & $5.28 / 53.49$ & +1.74 & 0.002 & 183 & 4.60 & $\begin{array}{c}\text { AHGGVSVFGGV } \\
\text { GERFVQAGSE } \\
\text { VSALLGR }\end{array}$ \\
\hline $132(\mathrm{~T} 48)$ & Q2MIB5 & $\begin{array}{l}\text { ATP synthase subunit } \\
\text { alpha } \\
\text { (Solanum lycopersicum) }\end{array}$ & $5.24 / 59.09$ & $5.14 / 55.43$ & -2.27 & 0.000 & 147 & 5.14 & $\begin{array}{l}\text { EAYPGDVFYLHSR } \\
\text { IAQIPVSEAYLGR }\end{array}$ \\
\hline $223(\mathrm{~T} 2)$ & K4AXS2 & $\begin{array}{l}\text { Glutamine synthetase } \\
\text { (Solanum lycopersicum) }\end{array}$ & $5.12 / 45.00$ & $6.29 / 46.85$ & +1.59 & 0.028 & 140 & 3.70 & $\begin{array}{l}\text { HETASIDQF } \\
\text { SWGVANR }\end{array}$ \\
\hline $256 \mathrm{~T}(48)$ & A0A075EZS4 & $\begin{array}{l}\text { Glyoxisomal malate } \\
\text { dehydrogenase } \\
\text { (Nicotiana tabacum) }\end{array}$ & $9.27 / 35.02$ & $8.40 / 37.94$ & -10.84 & 0.000 & 64 & 4.76 & $\begin{array}{l}\text { TGAEEVYQL } \\
\text { GPLNEYER }\end{array}$ \\
\hline \multicolumn{10}{|c|}{ Photosynthesis } \\
\hline${ }^{\star} 19(\mathrm{~T} 2)$ & K4D1V7 & $\begin{array}{c}\text { Ferredoxin-1 } \\
\text { (Solanum lycopersicum) }\end{array}$ & $3.54 / 15.67$ & $4.60 / 15.74$ & -1.58 & 0.001 & 31 & 14.60 & $\begin{array}{c}\text { LITPEGPFEFDCPD } \\
\text { DVSILDR }\end{array}$ \\
\hline *28 (T2) & K4CU43 & $\begin{array}{l}\text { Photosystem I reaction } \\
\text { center subunit IV A }\end{array}$ & $9.58 / 17.57$ & $9.77 / 14.86$ & +1.59 & 0.043 & 173 & 14.30 & $\begin{array}{l}\text { VNYANVSTNNY } \\
\text { ALDEVEEVK }\end{array}$ \\
\hline$\star 58(\mathrm{~T} 2)$ & K4B876 & $\begin{array}{c}\text { Chlorophyll a/b } \\
\text { binding protein } \\
\text { (Solanum lycopersicum) }\end{array}$ & $4.68 / 26.48$ & $5.15 / 28.20$ & +2.04 & 0.010 & 42 & 4.91 & SAPSSSPWYGPDR \\
\hline •58 (T48) & K4B876 & $\begin{array}{c}\text { Chlorophyll a/b } \\
\text { binding protein } \\
\text { (Solanum lycopersicum) }\end{array}$ & $4.68 / 26.48$ & $5.15 / 28.20$ & +1.95 & 0.001 & 42 & 4.91 & SAPSSSPWYGPDR \\
\hline $90(\mathrm{~T} 2)$ & К4B3Р9 & $\begin{array}{l}\text { Fructose-bisphosphate } \\
\text { aldolase } \\
\text { (Solanum lycopersicum) }\end{array}$ & $5.99 / 35.11$ & $6.07 / 42.87$ & -1.64 & 0.028 & 44 & 2.53 & SAAYYQQGAR \\
\hline $94(\mathrm{~T} 0)$ & K4B6C3 & $\begin{array}{l}\text { Fructose-bisphosphate } \\
\text { aldolase } \\
\text { (Solanum lycopersicum) }\end{array}$ & $5.43 / 37.24$ & $6.07 / 42.87$ & -2.08 & 0.046 & 70 & 2.53 & SAAYYQQGAR \\
\hline $96(\mathrm{~T} 2)$ & K4B6C3 & $\begin{array}{l}\text { Fructose-bisphosphate } \\
\text { aldolase } \\
\text { (Solanum lycopersicum) }\end{array}$ & $5.33 / 38.01$ & $6.07 / 42.88$ & -1.75 & 0.040 & 87 & 2.53 & SAAYYQQGAR \\
\hline $188(\mathrm{~T} 2)$ & P23322 & $\begin{array}{c}\text { Oxygen-evolving } \\
\text { enhancer protein } 1 \\
\text { (Solanum lycopersicum) }\end{array}$ & $5.03 / 32.87$ & $5.91 / 35 / 16$ & +1.81 & 0.023 & 86 & 2.72 & VPFLFTIK \\
\hline \multicolumn{10}{|c|}{ Stress and defense } \\
\hline 48 (T48) & K0I7G7 & $\begin{array}{l}\text { Thioredoxin peroxidase } \\
\text { (Nicotiana tabacum) }\end{array}$ & $4.70 / 24.67$ & $8.25 / 39.97$ & +2.24 & 0.016 & 90 & 5.19 & $\begin{array}{l}\text { SYNVLIPD } \\
\text { QGIALR }\end{array}$ \\
\hline $116(\mathrm{~T} 2)$ & A0A0G2SJC2 & $\begin{array}{c}\text { N2-acetylornithine } \\
\text { deacetylase } \\
\text { (Solanum lycopersicum) }\end{array}$ & $4.55 / 46.27$ & $4.79 / 48.30$ & -1.94 & 0.042 & 79 & 5.07 & $\begin{array}{l}\text { ATEEVVGYVEP } \\
\text { YSITGSLPLIR }\end{array}$ \\
\hline
\end{tabular}




\section{Continued}

\begin{tabular}{|c|c|c|c|c|c|c|c|c|c|}
\hline 303 (T48) & Q01413 & $\begin{array}{l}\text { Glucan endo-1,3-beta- } \\
\text { glucosidase B } \\
\text { (Solanum lycopersicum) }\end{array}$ & $9.76 / 35.56$ & $7.85 / 39.75$ & +1.70 & 0.027 & 150 & 6.67 & $\begin{array}{l}\text { LYDPNHGAL } \\
\text { NALRWFTD } \\
\text { PIVGFLR }\end{array}$ \\
\hline \multicolumn{10}{|c|}{ Transcription } \\
\hline${ }^{\star} 177(\mathrm{~T} 2)$ & K4C945 & $\begin{array}{l}\text { Chloroplast stem-loop } \\
\text { binding protein of } \\
41 \text { Kda B } \\
\text { (Solanum lycopersicum) }\end{array}$ & $6.64 / 40.87$ & $7.67 / 42.60$ & -1.94 & 0.036 & 213 & 8.71 & $\begin{array}{l}\text { FIGVFLSREGHQ } \\
\text { VTLFTRAGGF } \\
\text { PEPELVHYNPK }\end{array}$ \\
\hline \multicolumn{10}{|c|}{ Uncharacterized } \\
\hline $38(\mathrm{~T} 2)$ & A3A0W3 & $\begin{array}{l}\text { Uncharacterized } \\
\text { protein } \\
\text { (Oryza sativa subsp. } \\
\text { japônica) }\end{array}$ & $4.90 / 19.24$ & $10.36 / 29.68$ & +1.52 & 0.018 & 76 & 8.99 & $\begin{array}{c}\text { SSWNSPYYD } \\
\text { TSSYGAGSG } \\
\text { GGGGGGR }\end{array}$ \\
\hline
\end{tabular}

aID represents the identification number of the proteins identified in the two-dimensional gels. (T0), (T2), and (T48) at the time when the spot was differentially abundant. ${ }^{b}$ Number of access in UNIPROT. ${ }^{c}$ Isoelectrical (pI) points and experimental and theoretical molecular masses (MM). ${ }^{\mathrm{d}}$ Level of abundance

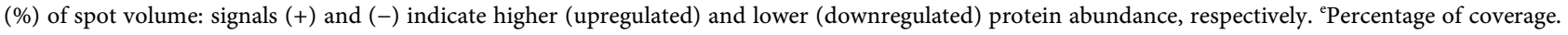

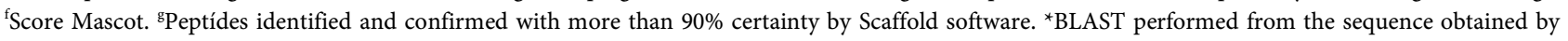
UNIPROT in Phytozome.

genotype, 15 were downregulated and 24 were upregulated (Table 2). After inoculation, an increase was noted in the relative abundance of most proteins involved in energy and metabolism processes, photosynthesis, stress, and defense, in addition to uncharacterized proteins. Most proteins related to transcription and even other proteins had reduced relative abundance (Figure 3 ).

Several proteins were identified in more than one spot on the same gel. The 17 spots identified in the Santa Clara genotype corresponded to 14 proteins (Table 1), while 39 spots being related to $\mathrm{BGH}-2127$, which corresponds to 25 proteins (Table 2). Three spots were identified as different forms of the protein fructose bisphosphate aldolase $(90,94$, and 96) in Santa Clara (Table 1). Two spots associated to the BGH-2127 genotype were identified as ATP synthase alpha subunit (122 and 125), three as ATP synthase beta subunit $(24,129$, and 132), four as subunit II of the reaction center of photosystem I (37, 140, 268, and 271), two as proteins involved in oxygen enrichment 1 (185 and 188), and two as proteins involved in oxygen enrichment 2 (43 and 47) (Table 2).

An important point observed from among the results was that the same protein represented by different spots had opposite levels of abundance. This was observed in spots $37,140,268$, and 271 , identified as subunit II of the reaction center of photosystem I for BGH-2127. Spots 37 and 268 were upregulated, while 271 was downregulated. It should be noted that spot 140 , differentially abundant in the three times evaluated, was upregulated at 0 and $48 \mathrm{~h}$ of inoculation and downregulated at $2 \mathrm{~h}$ of inoculation (Table 2 ).

\subsection{Correlation between mRNA and Abundance of Proteins}

The gene transcription levels (mRNA) encoding the 2-Cys peroxiredoxin BAS1 (spot 44) and thaumatin-like (spot 45) proteins evaluated for BGH-2127 did not 
Table 2. Differentially abundant proteins in the resistant genotype $B G H-2127$ after inoculation with $P$. infestans identified by mass spectrometry.

\begin{tabular}{|c|c|c|c|c|c|c|c|c|c|}
\hline \multirow{2}{*}{$\begin{array}{l}{ }^{\text {aID }} \\
\text { (Time) }\end{array}$} & \multirow{2}{*}{${ }^{\mathrm{b}}$ Access } & \multirow{2}{*}{$\begin{array}{c}\text { Protein } \\
\text { (organism) }\end{array}$} & \multicolumn{2}{|c|}{${ }^{c} \mathrm{pI} / \mathrm{MW}$} & \multirow{2}{*}{$\begin{array}{c}{ }^{\mathrm{d}} \text { Level of } \\
\text { abundance }\end{array}$} & \multirow{2}{*}{$\begin{array}{c}\text { Anova } \\
(\mathrm{P}< \\
0.05) \\
\end{array}$} & \multirow{2}{*}{$\begin{array}{c}\text { e Coverage } \\
(\%)\end{array}$} & \multirow{2}{*}{ Score } & \multirow{2}{*}{${ }^{\text {gPeptides identified }}$} \\
\hline & & & Experimental & Theoretical & & & & & \\
\hline \multicolumn{10}{|c|}{ Energy and metabolism } \\
\hline$\star^{\star} 24(\mathrm{~T} 0)$ & K4ASU4 & $\begin{array}{c}\text { ATP synthase } \\
\text { subunit beta } \\
\text { (Solanum lycopersicum) }\end{array}$ & $5.77 / 16.41$ & $5.30 / 14.57$ & +3.45 & 0.001 & 169 & 19.50 & $\begin{array}{l}\text { IGNNEITVLVNDAEK } \\
\text { TLNLSVLTPNR }\end{array}$ \\
\hline $\begin{array}{c}62 \\
\text { (T0) }\end{array}$ & M0ZMS6 & $\begin{array}{c}\text { Triosephosphate } \\
\text { isomerase } \\
\text { (Solanum tuberosum) }\end{array}$ & $5.37 / 27.83$ & $6.89 / 35.06$ & +1.95 & 0.006 & 359 & 17.20 & $\begin{array}{c}\text { FFVGGNWK } \\
\text { GGAFTGEISVEQVK } \\
\text { TFDVCFQQLK } \\
\text { VASPEQAQEVHVAVR } \\
\text { WVILGHSER }\end{array}$ \\
\hline $122(\mathrm{~T} 0)$ & Q2MI93 & $\begin{array}{c}\text { ATP synthase } \\
\text { subunit beta } \\
\text { (Solanum lycopersicum) }\end{array}$ & $5.50 / 54.28$ & $5.28 / 53.49$ & +2.85 & 0.003 & 180 & 4.60 & $\begin{array}{c}\text { AHGGVSVFGGVGER } \\
\text { FVQAGSEVSALLGR }\end{array}$ \\
\hline 125 (T0) & Q2MI93 & $\begin{array}{c}\text { ATP synthase } \\
\text { subunit beta } \\
\text { (Solanum lycopersicum) }\end{array}$ & $5.39 / 54.21$ & $5.28 / 53.50$ & +2.33 & 0.003 & 57 & 2.30 & AHGGVSVFGGVGER \\
\hline $129(\mathrm{~T} 2)$ & Q2MIB5 & $\begin{array}{c}\text { ATP synthase } \\
\text { subunit alpha } \\
\text { (Solanum lycopersicum) }\end{array}$ & $4.99 / 55.60$ & $5.14 / 55.43$ & -1.82 & 0.004 & 180 & 5.13 & $\begin{array}{l}\text { EAYPGDVFYLHSR } \\
\text { IAQIPVSEAYLGR }\end{array}$ \\
\hline $132(\mathrm{~T} 2)$ & Q2MIB5 & $\begin{array}{c}\text { ATP synthase } \\
\text { subunit alpha } \\
\text { (Solanum lycopersicum) }\end{array}$ & $5.24 / 59.09$ & $5.14 / 55.43$ & -4.04 & 0.036 & 147 & 5.14 & $\begin{array}{l}\text { EAYPGDVFYLHSR } \\
\text { IAQIPVSEAYLGR }\end{array}$ \\
\hline
\end{tabular}

Photosynthesis

\begin{tabular}{|c|c|c|c|c|c|c|c|c|c|}
\hline $5(\mathrm{~T} 2)$ & A9S3R8 & $\begin{array}{l}\text { Ribulose bisphosphate } \\
\text { carboxylase small chain } \\
\text { (Physcomitrella patens } \\
\text { subsp. patens) }\end{array}$ & $4.81 / 11.80$ & $8.20 / 20.16$ & -1.57 & 0.028 & 178 & 6.63 & ENNSSPGYYDGR \\
\hline${ }^{\star} 19(\mathrm{~T} 2)$ & K4D1V7 & $\begin{array}{c}\text { Ferredoxin-1 } \\
\text { (Solanum lycopersicum) }\end{array}$ & $3.54 / 15.67$ & $4.60 / 15.74$ & -1.72 & 0.028 & 31 & 14.60 & $\begin{array}{l}\text { LITPEGPFEFDC } \\
\text { PDDVSILDR }\end{array}$ \\
\hline${ }^{*} 21(\mathrm{~T} 2)$ & K4C6T7 & $\begin{array}{l}\text { Glycine cleavage system } \\
\text { H protein } 3 \\
\text { (Solanum lycopersicum) }\end{array}$ & $3.89 / 15.93$ & $4.73 / 17.66$ & +2.28 & 0.024 & 40 & 5.52 & YASSHEWVK \\
\hline$\star 28(\mathrm{~T} 2)$ & K4CU43 & $\begin{array}{l}\text { Photosystem I reaction } \\
\text { center subunit IV A } \\
\text { (Solanum lycopersicum) }\end{array}$ & $9.58 / 17.57$ & $9.77 / 14.86$ & -2.58 & 0.002 & 173 & 14.30 & $\begin{array}{l}\text { VNYANVSTNN } \\
\text { YALDEVEEVK }\end{array}$ \\
\hline 37 (T0) & P12372 & $\begin{array}{c}\text { Photosystem I reaction } \\
\text { center subunit II } \\
\text { (Solanum lycopersicum) }\end{array}$ & $9.77 / 20.61$ & $9.71 / 22.96$ & +17.49 & 0.005 & 101 & 3.37 & INYQFYR \\
\hline $43(\mathrm{~T} 2)$ & K4CEP4 & $\begin{array}{c}\text { Oxygen-evolving } \\
\text { enhancer protein } 2 \\
\text { (Solanum lycopersicum) }\end{array}$ & $5.45 / 22.97$ & $7.63 / 27.86$ & +2.45 & 0.015 & 185 & 9.30 & $\begin{array}{c}\text { EYYYLSVLTR } \\
\text { SITDYGSPEEFLSK }\end{array}$ \\
\hline 43 (T48) & K4CEP4 & $\begin{array}{c}\text { Oxygen-evolving } \\
\text { enhancer protein } 2 \\
\text { (Solanum lycopersicum) }\end{array}$ & $5.45 / 22.97$ & $7.63 / 27.86$ & +1.82 & 0.038 & 185 & 9.30 & $\begin{array}{c}\text { EYYYLSVLTR } \\
\text { SITDYGSPEEFLSK }\end{array}$ \\
\hline
\end{tabular}




\section{Continued}

\begin{tabular}{|c|c|c|c|c|c|c|c|c|c|}
\hline 47 (T0) & K4CEP4 & $\begin{array}{c}\text { Oxygen-evolving } \\
\text { enhancer protein } 2 \\
\text { (Solanum lycopersicum) }\end{array}$ & $5.19 / 24.58$ & $7.63 / 27.86$ & +1.59 & 0.038 & 71 & 3.88 & EYYYLSVLTR \\
\hline 53 (T2) & A0A061FWJ7 & $\begin{array}{c}\text { Ribulose-phosphate } \\
\text { 3-epimerase } \\
\text { ( Theobroma cacao) }\end{array}$ & $6.99 / 26.08$ & $6.96 / 26.28$ & -2.46 & 0.043 & 165 & 14.30 & $\begin{array}{l}\text { AGADIVSVHCEQSSTIHL } \\
\text { HRGVNPWIEVDGGVGPK }\end{array}$ \\
\hline 140 (T0) & P12372 & $\begin{array}{c}\text { Photosystem I reaction } \\
\text { center subunit II } \\
\text { (Solanum lycopersicum) }\end{array}$ & $9.73 / 17.98$ & $9.71 / 22.96$ & +12.44 & 0.006 & 50 & 3.37 & INYQFYR \\
\hline 140 (T2) & $\mathrm{P} 12372$ & $\begin{array}{c}\text { Photosystem I reaction } \\
\text { center subunit II } \\
\text { (Solanum lycopersicum) }\end{array}$ & $9.73 / 17.98$ & $9.71 / 22.96$ & -2.10 & 0.045 & 50 & 3.37 & INYQFYR \\
\hline 140 (T48) & P12372 & $\begin{array}{c}\text { Photosystem I reaction } \\
\text { center subunit II } \\
\text { (Solanum lycopersicum) }\end{array}$ & $9.73 / 17.98$ & $9.71 / 22.96$ & +1.51 & 0.032 & 50 & 3.37 & INYQFYR \\
\hline 185 (T0) & P23322 & $\begin{array}{c}\text { Oxygen-evolving } \\
\text { enhancer protein } 1 \\
\text { (Solanum lycopersicum) }\end{array}$ & $5.23 / 32.50$ & $5.91 / 35 / 15$ & +2.23 & 0.014 & 81 & 2.43 & VPFLFTIK \\
\hline 188 (T0) & P23322 & $\begin{array}{c}\text { Oxygen-evolving } \\
\text { enhancer protein } 1 \\
\text { (Solanum lycopersicum) }\end{array}$ & $5.03 / 32.87$ & $5.91 / 35 / 16$ & +2.04 & 0.026 & 86 & 2.72 & VPFLFTIK \\
\hline${ }^{*} 226(\mathrm{~T} 2)$ & K4CGI6 & $\begin{array}{c}\text { Peroxisomal } \\
\text { (S)-2-hydroxy-acid } \\
\text { oxidase GLO5 } \\
\text { (Solanum lycopersicum) }\end{array}$ & $9.64 / 37.34$ & $8.98 / 40.64$ & -6.57 & 0.001 & 48 & 2.70 & IPVFLDGGVR \\
\hline 268 (T0) & P12372 & $\begin{array}{l}\text { Photosystem I } \\
\text { reaction center subunit II } \\
\text { (Solanum lycopersicum) }\end{array}$ & $9.76 / 21.56$ & $9.71 / 22.96$ & +3.84 & 0.004 & 48 & 3.37 & INYQFYR \\
\hline 271 (T48) & P12372 & $\begin{array}{l}\text { Photosystem I } \\
\text { reaction center subunit II } \\
\text { (Solanum lycopersicum) }\end{array}$ & $8.63 / 19.23$ & $9.71 / 22.96$ & -2.08 & 0.023 & 40 & 3.37 & INYQFYR \\
\hline $275(\mathrm{~T} 2)$ & P05349 & $\begin{array}{l}\text { Ribulose bisphosphate } \\
\text { carboxylase } \\
\text { small chain } 3 \mathrm{~B}\end{array}$ & $4.79 / 12.22$ & $6.72 / 20.21$ & -2.38 & 0.020 & 243 & 13.90 & $\begin{array}{l}\text { AYPQAWVR } \\
\text { IIGFDNVR } \\
\text { KAYPQAWVR } \\
\text { SPGYYDGR }\end{array}$ \\
\hline
\end{tabular}

\begin{tabular}{|c|c|c|c|c|c|c|c|c|c|}
\hline \multicolumn{10}{|c|}{ Stress and defense } \\
\hline${ }^{\star} 44$ (T0) & K4D389 & $\begin{array}{l}\text { 2-Cys peroxiredoxin BAS1 } \\
\text { (Solanum lycopersicum) }\end{array}$ & $4.53 / 23.80$ & $6.00 / 29.73$ & +1.67 & 0.006 & 155 & 14.2 & $\begin{array}{c}\text { AYNVLIPDQGIALR } \\
\text { VNTEILGVSVDSV } \\
\text { FSHLAWVQTER }\end{array}$ \\
\hline *45 (T48) & К4СР63 & $\begin{array}{c}\text { Thaumatin Family } \\
\text { (Solanum lycopersicum) }\end{array}$ & $9.65 / 24.73$ & $6.67 / 27.60$ & +3.35 & 0.012 & 119 & 8.13 & $\begin{array}{l}\text { GQTWVINAPR } \\
\text { TNCNFDGAGR }\end{array}$ \\
\hline $51(\mathrm{~T} 0)$ & I0CC94 & $\begin{array}{l}\text { 2-cys peroxiredoxin } \\
\text { (Tamarix hispida) }\end{array}$ & $4.54 / 24.84$ & $6.90 / 30.02$ & +1.95 & 0.021 & 91 & 6.60 & TVIDESLVAGFTIR \\
\hline *84 (T0) & K4BX60 & $\begin{array}{l}\text { Leucine rich repeat } \\
\text { N-terminal domain } \\
\text { (Solanum lycopersicum) }\end{array}$ & $5.44 / 32.71$ & $6.23 / 78.66$ & +1.63 & 0.032 & 34 & 1.12 & VVSVSIPR \\
\hline 93 (Т0) & K4CAF9 & $\begin{array}{c}\text { Carboxypeptidase } \\
\text { (Solanum lycopersicum) }\end{array}$ & $4.66 / 36.59$ & $5.84 / 56.02$ & +1.64 & 0.038 & 260 & 7.03 & $\begin{array}{l}\text { HYAGYVNIDESHGK } \\
\text { NLYYYFVESER } \\
\text { WFEIYPEFLK }\end{array}$ \\
\hline
\end{tabular}




\section{Continued}

\begin{tabular}{|c|c|c|c|c|c|c|c|c|c|}
\hline $210^{*}(\mathrm{~T} 0)$ & K4BJU1 & $\begin{array}{c}\text { Protease inhibitor } \\
\text { (Solanum lycopersicum) }\end{array}$ & $9.13 / 21.57$ & $7.48 / 24.99$ & -2.79 & 0.026 & 85 & 5.43 & LFNIQFDIPTFR \\
\hline $210^{*}(\mathrm{~T} 48)$ & K4BJU1 & $\begin{array}{c}\text { Protease inhibitor } \\
\text { (Solanum lycopersicum) }\end{array}$ & $9.13 / 21.57$ & $7.48 / 24.99$ & -3.07 & 0.008 & 85 & 5.43 & LFNIQFDIPTFR \\
\hline $213^{*}(\mathrm{~T} 0)$ & K4D389 & $\begin{array}{l}\text { 2-Cys peroxiredoxin BAS1 } \\
\text { (Solanum lycopersicum) }\end{array}$ & $4.40 / 23.81$ & $6.00 / 29.73$ & +1.56 & 0.017 & 229 & 11.20 & $\begin{array}{c}\text { AYNVLIPDQGIALR } \\
\text { EGVIQHSTINNLGIGR }\end{array}$ \\
\hline 303 (T48) & Q01413 & $\begin{array}{c}\text { Glucan } \\
\text { endo-1,3-beta-glucosidase B } \\
\text { (Solanum lycopersicum) }\end{array}$ & $9.76 / 35.56$ & $7.85 / 39.75$ & -6.32 & 0.005 & 150 & 6.67 & $\begin{array}{l}\text { LYDPNHGALNALR } \\
\text { WFTDPIVGFLR }\end{array}$ \\
\hline \multicolumn{10}{|c|}{ Transcription } \\
\hline *265 (T0) & K4BK45 & $\begin{array}{c}\text { Splicing factor } 3 \mathrm{~b}, \\
\text { subunit } 4 \\
\text { (Solanum lycopersicum) }\end{array}$ & $4.14 / 30.61$ & $4.68 / 27.23$ & +3.33 & 0.013 & 104 & 4.73 & IYVGNIPWDIDDAR \\
\hline$\star 265$ (T48) & K4BK45 & $\begin{array}{c}\text { Splicing factor } 3 \mathrm{~b}, \\
\text { subunit } 4 \\
\text { (Solanum lycopersicum) }\end{array}$ & $4.14 / 30.61$ & $4.68 / 27.23$ & +1.51 & 0.043 & 104 & 4.73 & IYVGNIPWDIDDAR \\
\hline 270 (T48) & K4BVX5 & $\begin{array}{c}\text { Peptidyl-prolyl cis-trans } \\
\text { isomerase } \\
\text { (Solanum lycopersicum) }\end{array}$ & $8.67 / 17.14$ & $6.75 / 24.73$ & -5.24 & 0.034 & 303 & 18.80 & $\begin{array}{l}\text { SGDTVVVDWDGYTI } \\
\text { GYYGRVGSQEVIP } \\
\text { AFEEAITGIALGGIR }\end{array}$ \\
\hline \multicolumn{10}{|c|}{ Other proteins } \\
\hline $277(\mathrm{~T} 2)$ & Q8RZX3 & $\begin{array}{l}\text { Os01g0915900 protein } \\
\text { (Oryza sativa subsp. } \\
\text { japônica) }\end{array}$ & $6.05 / 26.02$ & $8.75 / 23.33$ & -2.36 & 0.036 & 65 & 8.99 & $\begin{array}{c}\text { SSWNSPYYDTSSYG } \\
\text { AGSGGGGGGGR }\end{array}$ \\
\hline 104 (T48) & A3A0W3 & $\begin{array}{c}\text { Uncharacterized protein } \\
\text { (Oryza sativa subsp. } \\
\text { japônica) }\end{array}$ & $5.98 / 40.08$ & $10.36 / 29.68$ & +1.52 & 0.027 & 59 & 8.99 & $\begin{array}{c}\text { SSWNSPYYDTSSYG } \\
\text { AGSGGGGGGGR }\end{array}$ \\
\hline 215 (T0) & $\mathrm{A} 3 \mathrm{~A} 0 \mathrm{~W} 3$ & $\begin{array}{l}\text { Uncharacterized protein } \\
\text { (Oryza sativa subsp. } \\
\text { japônica) }\end{array}$ & $6.14 / 43.16$ & $10.36 / 29.68$ & +2.76 & 0.002 & 70 & 8.99 & $\begin{array}{c}\text { SSWNSPYYDTSSYG } \\
\text { AGSGGGGGGGR }\end{array}$ \\
\hline
\end{tabular}

a ID represents the identification number of the proteins identified in the two-dimensional gels. (T0), (T2), and (T48) at the time when the spot was differentially abundant. ${ }^{b}$ Number of access in UNIPROT. ${ }^{c}$ Isoelectrical (pI) points and experimental and theoretical molecular masses (MM). ${ }^{\mathrm{d}}$ Level of abundance (\%) of spot volume: signals (+) and (-) indicate higher (upregulated) and lower (downregulated) protein abundance, respectively. ${ }^{\mathrm{e} P e r c e n t a g e}$ of coverage.

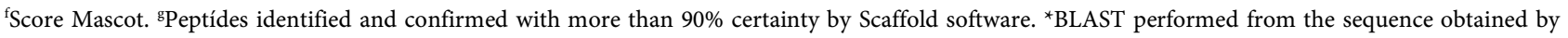
UNIPROT in Phytozome.

correlate with the abundance levels of the respective proteins. Expression of the gene encoding 2-Cys peroxiredoxin BAS1 significantly decreased at time 0 (zero) for the inoculated treatment, while its corresponding protein obtained greater abundance. For thaumatin-like (spot 45), no difference was noted in the expression level of the gene coding for this protein at $48 \mathrm{~h}$ of inoculation; however, the abundance of the respective protein was higher in the inoculated treatment. The relative abundance of proteins may or may not be proportional to the mRNA levels since, after mRNA synthesis, different regulatory processes occur, such as post-transcriptional, post-translational, and protein degradation, which act to control protein abundance. 


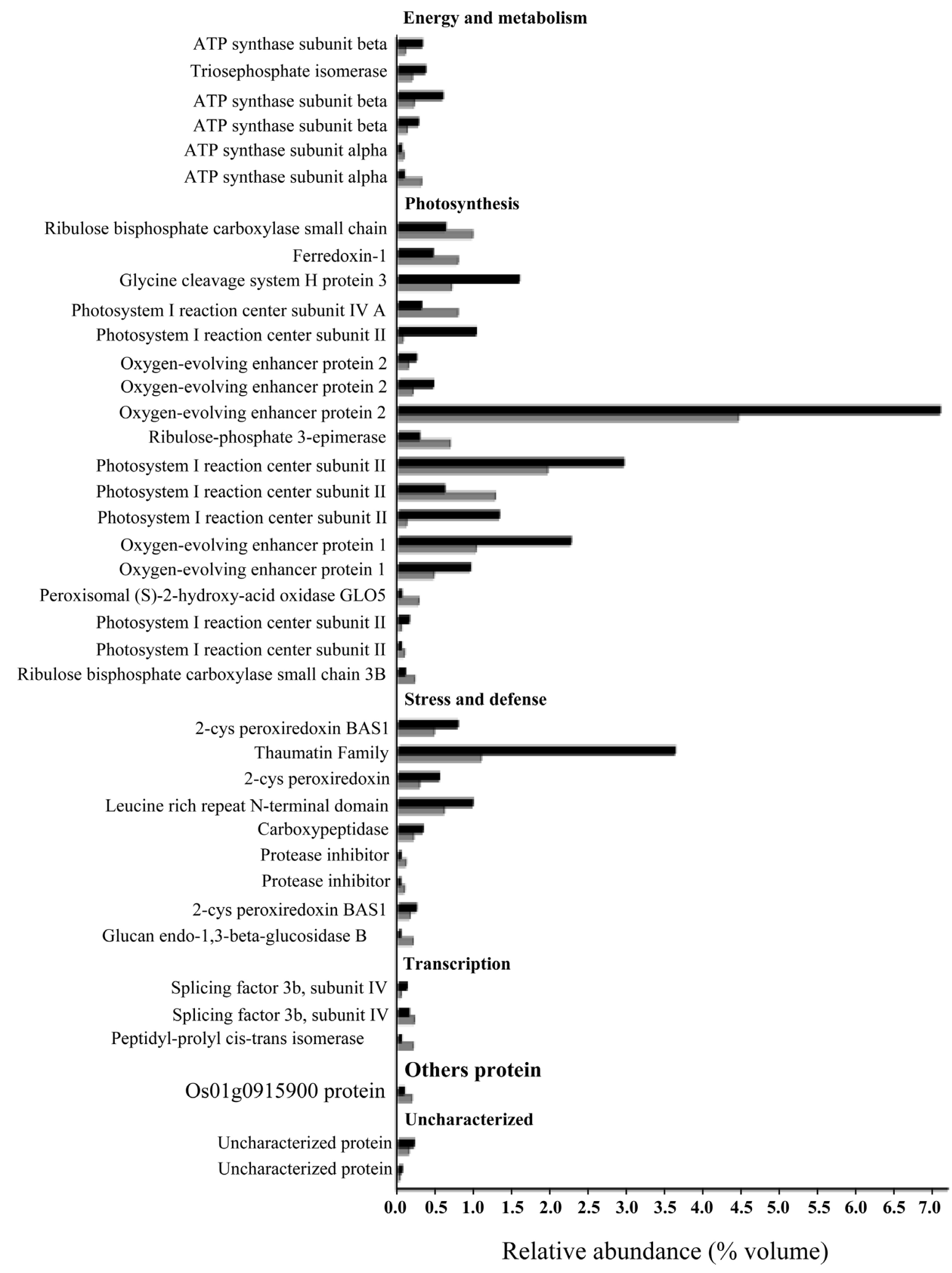

Down-regulated Up-regulated

Figure 3. Relative abundance (\% volume) of differentially accumulated proteins considering treatments, inoculated and not inoculated with $P$. infestans in $B G H-2127$ genotype. 


\subsection{Analysis of Protein-Protein Interaction Networks}

The observed interactions among proteins identified to be associated with Santa Clara genotype occurred among those related to the photosynthetic process as well as between the metabolic and energy proteins. The proteins thioredoxin peroxidase (spot 48), N2-acetylornithine (spot 116), and $\beta$-1,3 endo glucan glucosidase B (spot 303) have no functional relationship to each other and with other proteins (Figure 4).

In the protein interaction network of the BGH-2127 genotype, for stress-defense-related leucine-rich N-terminal domain (spot 84), interaction was observed with the ribulose 3-phosphate epimerase protein (spot 53), which in turn interacted with ribulose bisphosphate carboxylase chain small chain (spot 5) and ribulose bisphosphate carboxylase small chain 3B (spot 275). Two other networks of observed interactions occurred between the proteins related to the photosynthetic process and also between energy proteins and metabolism. For the other proteins related to stress and defense, transcription and other proteins, no functional relationship was observed (Figure 5).

\section{Discussion}

Phytophthora infestans etiological agent of tomato late blight was classified from

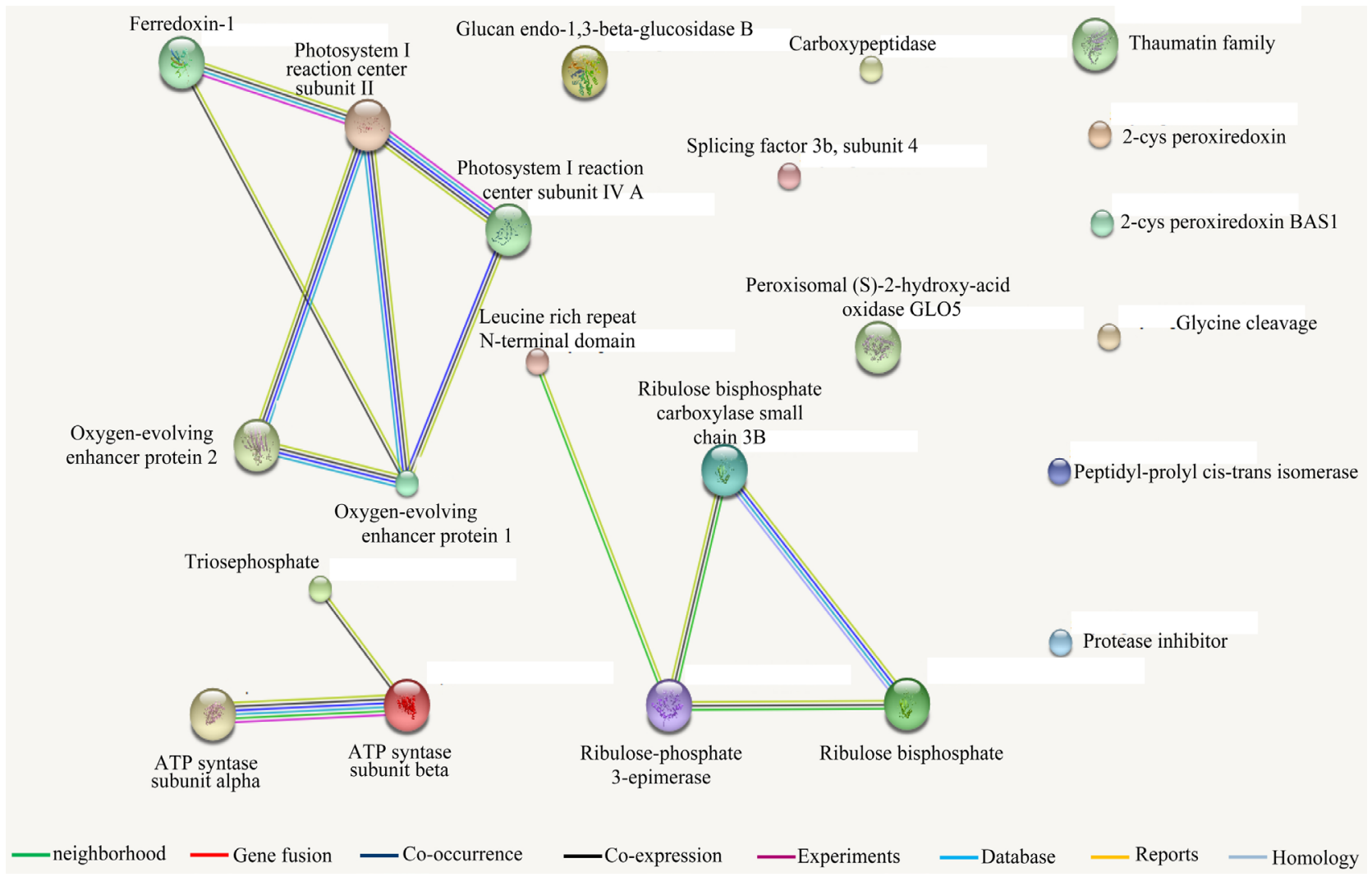

Figure 4. The protein-protein interaction network analyzed by the String software from differentially abundant proteins for the inoculated and uninoculated Santa Clara genotype. Lines of different colors represent evidence of associations, according to the legend. 


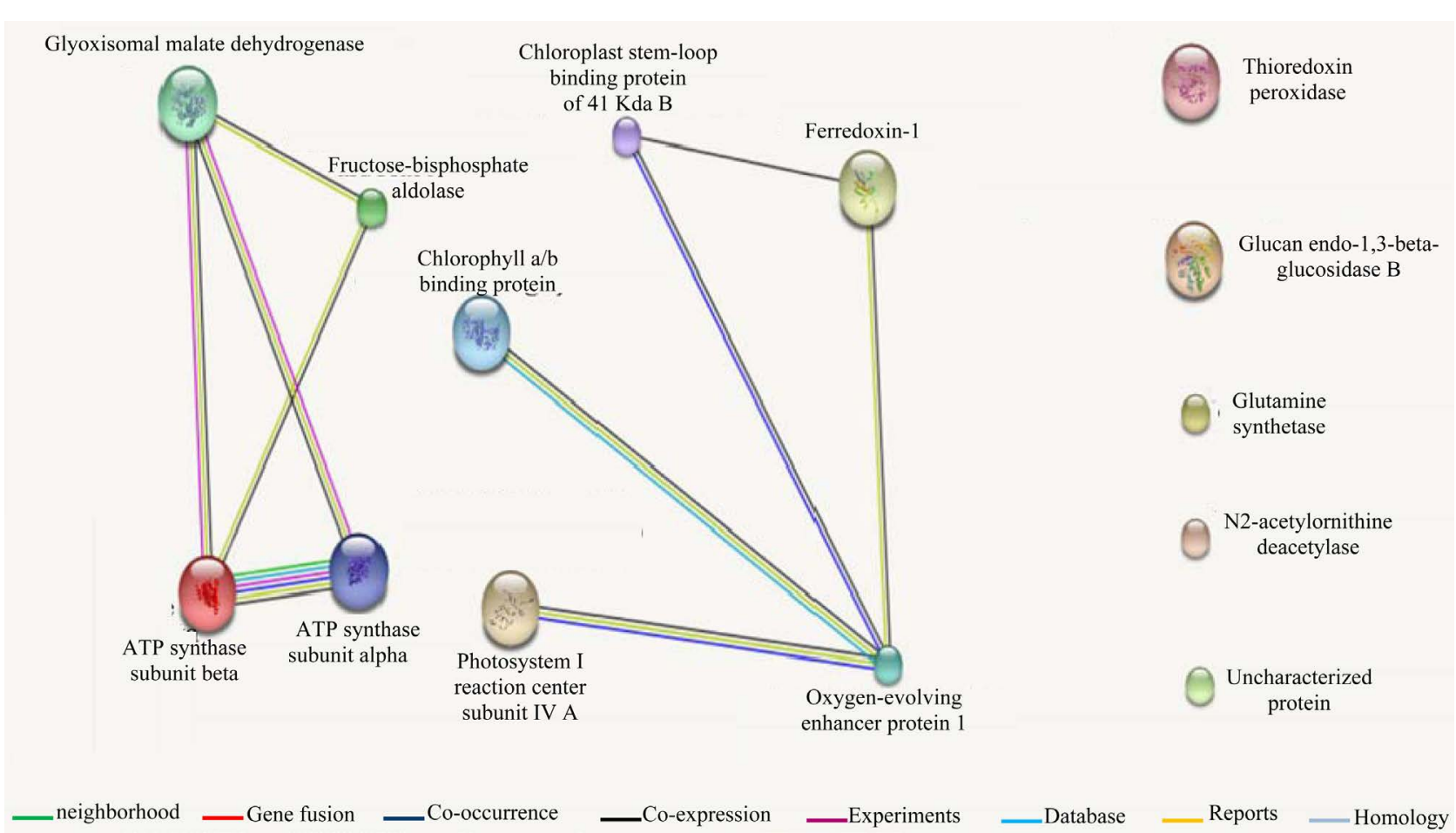

Figure 5. The protein-protein interaction network analyzed by the String software from differentially abundant proteins for the inoculated and uninoculated $B G H-2127$ genotype. Lines of different colors represent evidence of associations according to the legend.

the scientific and economic point of view as the most relevant species among oomycetes that attack plants [31]. Despite the knowledge of the importance of this disease, resistant tomato cultivars are not available in the market, which reflects the difficulty of working with this pathogen in breeding programs [5]. Resistance source to the blight was identified in wild tomato species [32], however, when these genotypes were used in breeding programs, problems common to genetic trawling occur, because QTL's related to resistance against re-blight affect the characteristic morphoagronomics of interest [33]. An alternative to reverse this problem is to use resistance sources belonging to the same species that needs to be improved (S. lycopersicum), such as BGH-2127 access [7]. The differential characteristic of this genotype will provide faster recovery of the desired agronomic characteristics.

\subsection{Proteomic Responses of Contrasting Genotypes in the Resistance to the Late Blight}

Based on the variations in the differential abundance of proteins identified at different times $(0,2$, and $48 \mathrm{~h})$ before and after inoculation, their relationships with different biological processes were considered, aiming to demonstrate the possible contributions to the resistance to late blight from BGH-2127. Infection by the late blight induced a greater change in the number of proteins with differential abundance in the genotype BGH-2127 in relation to the Santa Clara genotype. 
The proteins identified were classified into different functional groups, confirming that the resistance of plants to pathogens results from several physiological factors and/or biochemical mechanisms [34]. For both the genotypes, the groups of functional classifications were practically the same, being related to the processes of energy and metabolism, photosynthesis, stress and defense, transcription, and uncharacterized features. The exception was the group of other proteins related to BGH-2127 access. However, only six differentially abundant proteins were found to be common to both the genotypes. Among these proteins, Ferredoxin-1 and ATP synthase alpha subunit were downregulated and ATP synthase beta subunit and protein involved in oxygen enrichment 2 were upregulated, whereas the IV subunit of the reaction center of photosystem I and Glucan endo-1,3-beta-glucosidase B obtained opposite patterns in both genotypes. The variability between proteins with differential abundance during infection by late blight evidences different responses among the evaluated genotypes.

Among the proteins found unique to each genotype, some were identified in more than one spot on the same gel. For the Santa Clara genotype, spots 90, 94, and 96 were identified as the protein fructose bisphosphate aldolase. In the genotype BGH-2127, two spots were identified as ATP synthase alpha subunit (122 and 125), three as ATP synthase beta subunit (24,129, and 132), four as subunit II of the reaction center of photosystem I (37, 140, 268, and 271), two as proteins involved in oxygen enrichment 1 (185 and 188), and two as proteins involved in oxygen enrichment 2 (43 and 47). These results indicated spots with different values of molecular mass (MM) and isoelectric point (pI) for the same protein, which occurred due to changes in the proteome that can be attributed to post-translational modifications or the presence of different forms of the same protein of a given functional family [35]. Post-translational modifications are important processes as they influence the activity and function of proteins by linking them with other functional groups [36].

Proteins represented by spots $37,140,268$, and 271 were identified as subunit II of the reaction center of photosystem I with different levels of abundance (some upregulated and other downregulated spots). One hypothesis for this phenomenon is that the different forms of protein play distinct molecular functions and are also responsible for the regulation of complex mechanisms during pathogen infection [35].

\subsection{Proteins Are Related to Energy and Metabolism}

In plants, many proteins are involved in the metabolic and energetic pathways, as they are considered important in response to infection [37], because they mobilize high metabolic costs to overcome pathogen attack [38]. Significant variations in the energy-related proteins and metabolism between the two treatments (inoculated and control not inoculated with $P$. infestans were evident. Differences in the regulation of proteins of this functional group can contribute to resistance to the re-chemistry of BGH-2127 in comparison with that of Santa Clara 
genotype. Approximately $67 \%$ of the proteins involved in this process for BGH-2127 had increased relative abundance level after inoculation, whereas, for Santa Clara, only half of these proteins showed an increase in the level. The increase in energy-related protein abundance and metabolism in infected plants may be justified by the fact that these plants have a higher energy demand to overcome the pathogen attack, which usually occurs by increased respiration [39].

Among the proteins that showed increased levels of abundance after inoculation with the pathogen for BGH-2127, it is highlighted that they form a part of the ATP synthase complex, which consists of several subunits and use the transmembrane proton gradient for cellular ATP biosynthesis [40]. Considering plant resistance to pathogens, cellular ATP plays an important role as a signaling molecule in response to stress, including those caused by pathogens [41].

Triphosphate isomerase is a key glycolytic pathway protein that catalyzes the interconversion between glyceraldehyde-3-phosphate and dihydroxyacetone phosphate. This protein has often been identified as a potential target of both glutathionylation and nitrosylation in proteomic studies, suggesting that its activity can be regulated under stress conditions [42]. In the stages of development of the phytopathogenicoomycete Phytophthora capsici, the protein triphosphate isomerase was upregulated in the presence of the pathogen hyphae [43].

\subsection{Photosynthesis-Related Proteins}

Photosynthesis is an important metabolic process that broadly contributes to the overall state of cellular energy for redox balance by providing NADPH, ATP, and carbon skeletons that support plant growth. In addition, they stimulate the initiation and maintenance of responses against external stress [44], which play the key role in host defense, which is one of the main processes affected [45]. Plants when subjected to some type of stress usually respond with a decrease in the synthesis of cellular proteins and an increase in the specific synthesis of proteins involved in defense mechanisms [46]. This indicates that, during a pathogen attack, biosynthesis of defense-related compounds is a priority for a plant, while other cellular activities are reduced, such as in the case of photosynthesis, until pathogen growth is disrupted [39] [47].

$P$. infestans is a hemibiotrophic pathogen, the infection of plants by this pathogen involves the transition from an asymptomatic initial biotrophic phase to a necrotrophic state, which is characterized by cell death [13]. In this context, the maintenance of photosynthesis would be advantageous for the development of late blight; therefore, reduction of photosynthesis is beneficial to the host and can be an important part in the defense of the plant, because the reduction of photosynthesis may deprive the pathogen of important nutrients [48]. For BGH-2127, after inoculation with $P$. infestans, an increase in the relative abundance of most proteins involved in the photosynthetic process was noticed; it was upregulated in ten proteins and downregulated in eight. However, it was 
noted that approximately $88 \%$ of the downregulated proteins (spots $5,19,28,53$, 140,226 , and 275) were differentially accumulated in time $2 \mathrm{~h}$ after inoculation, which corresponds to the biotrophic infection phase described in a previous study [13]. For the Santa Clara genotype, there existed a balance between the relative abundance levels of the proteins identified at $2 \mathrm{~h}$ after inoculation, with $50 \%$ of these down-regulated (spots 19, 90, and 96). These results also indicate that photosynthesis is affected differently among the genotypes evaluated during blight infection.

\subsection{Proteins Related to Stress and Defense}

The stress and defense responses of an organism, including, in plants, play an important role during cellular development against pathogen infection [35]. Among the proteins identified for the genotypes BGH-2127 and Santa Clara, $20.5 \%$ and $17.6 \%$, respectively, belong to the stress and defense group. Only the $\beta-1,3$ endoglucan glucosidase B (spot 303) protein differentially abundant $48 \mathrm{~h}$ after inoculation was found to be common to both the genotypes. However, opposite proteins abundance levels were observed, with values equal to -6.32 for BGH-2127 and +1.70 for Santa Clara, evidencing that this protein is not the major protein involved in the resistance of BGH-2127 and that different defense mechanisms are used by these genotypes.

Another protein that had reduced levels of relative abundance was the protease inhibitor (spot 210), which differentially accumulated at times 0 and $48 \mathrm{~h}$ after inoculation. During the infection process, the pathogen produces enzymes that target host cells, which in turn encode proteins with protease inhibitory activity to suppress the enzymatic activity of the pathogen [49]. Due to the reduction of the levels of this protein against the infection of the late blight, it is evident that the protease inhibitor protein is not the main defense mechanism used by the resistant genotype.

Two proteins related to oxidative stress have relative abundance that increased at time 0 after inoculation for BGH-2127, 2-cis peroxiredoxin BAS1 (spots 44 and 213), and 2-cis peroxiredoxin (spot 51). In plants, the attack of pathogens results in the rapid formation of reactive oxygen species, which can degrade proteins [50]. Reactive oxygen species can be eliminated by a network of enzymatic and non-enzymatic antioxidants like peroxiredoxins [51], which justifies the increase in the relative abundance of these proteins immediately after inoculation. Peroxiredoxins are a part of subfamilies in which the peroxidases are subdivided [52]. When they act in defense of cells against oxidative explosion, peroxidases consume hydrogen peroxide in the cytosol, vacuole, cell wall, and extracellular space. They are also linked to metabolic processes, lignin, and suberine formation, structuring and stretching of the cell wall, and hypersensitivity reactions, making it difficult for the pathogen to invade the plant [9] [53].

The differentially abundant spot 45 after $48 \mathrm{~h}$ of inoculation was identified with a protein from the thaumatin-like family. Proteins of this family are in- 
volved in the plant defense system against biotic and abiotic stresses [54], including important functions like resistance to pathogens, cold tolerance, salinity, and resistance to drought [55]. The abundance level of thaumatin was +3.45 times greater as compared to the control treatment, indicating the importance of this protein for resistance of $\mathrm{BGH}-2127$, since the presence of thaumatin-likeprotein has been associated with activity against oomycetes [10]. The proteins of the thaumatin-like family belong to group 5 (PR-5) of proteins related to pathogenesis [10]. Thaumatin's act by inhibiting the growth of hyphae and reduce the germination of spurs, probably by membrane permeabilization and/or by interaction with pathogen receptors [56]. The PR-5 has a strong affinity and hydrolytic activity for 1,3- $\beta$-glucan, which extracellularly detect $1,3-\beta$ Glucan due to the presence of a kinase domain and owing to a transmembrane potential [10]. The significant ability of thaumatin to degrade 1,3 - $\beta$-glucan is a strong indication of mechanisms associated with BGH-2127-access resistance, since the cell wall of oomycetes is composed mainly of this polymer [57]. In molecular studies involving the pathosystem Zingiberzerumbetvs Pythium aphaniderm for ZzPR5 protein belonging to the family of thaumatins, it was observed that the constituent amino acids of the protein hydrolyze 1,3- $\beta$-glucan, suggesting a potential anti-oomiceto activity [58]. In the specific case of the Phytophthora infestans oomycete, resistance tests on transgenic potatoes elucidated the potential of thaumatin-like protein against the pathogen, as there are no efficient control methods or resistant cultivars. The overexpression of thaumatin-like genes was found to be responsible for the substantial increase in the pathogen resistance [59].

Carboxypeptidase (spot 93) is a proteolytic protein involved in several cellular processes [60] are responsible for protein metabolism and in hydrolyzing peptides acting at the ends of the protein [61]. The observed increase in the relative abundance of this protein may contribute to the retention of BGH-2127, since carboxypeptidases are involved in the regulation of defense against infection by pathogens and oxidative stress [62].

Spot 84 was identified as the Leucine repeat rich N-terminal domain protein. Most dominant $\mathrm{R}$ genes encode proteins of this class, the structure of which is composed of an $\mathrm{N}$-terminal domain, a nucleotide-linked central domain and a leucine-rich C-terminal domain [63]. This protein functions as an intracellular receptor that detects pathogen-affecting proteins, which activates a set of defense responses associated with programmed cell death [64]. Effector-triggered immunity is a rapid response of the plant to the pathogen's attack; therefore, a +1.63 -fold increase was noted in the relative abundance of the leucine-rich $\mathrm{N}$-terminal domain protein at $0 \mathrm{~h}$ after inoculation. In tomato culture, a leucine-rich protein (CC-NBS-LRR) has been reported to confer resistance to $P$. infestans [65].

\subsection{Proteins Related to Transcription}

Two transcript-related proteins were differentially accumulated in BGH-2127. 
The protein-splicing factor 3b, subunit 4 (spot 265), was differentially accumulated at times 0 and $48 \mathrm{~h}$ after inoculation, both showing upregulation. Splicing is a process that removes the introns and binds the exons after RNA transcription. In this context, splicing factor proteins are important to maintain efficient processing of RNA under stress conditions. Post-transcriptional mechanisms based on splicing regulate the activation of pre-existing molecules to ensure an immediate response to stress [66]. The second protein identified for transcription was peptidyl-prolyl cis-trans isomerase (spot 270) differentially acclimated in $48 \mathrm{~h}$ of inoculation. This protein is considered to be a part of the plant's immume system that catalyzes the isomerization of peptide bonds in proline residues to specifically regulate protein conformation changes [67]. Peptil-prolylcis-trans isomerases are known to interact with other biological units to facilitate protein folding, regulate developmental processes, and certain aspects related to stress responses and cell death [68]. There is increasing evidence pointing to functions associated with plant defense against pathogens exerted by proteins members of the peptidyl-prolyl-cis-trans isomerase family [69].

\subsection{Protein-Protein Interaction Network}

Proteins do not act as individual units in cells, but rather in conjunction with other proteins to form certain networks of interactions [35]. To determine how the late blight interacts with tomato proteins and affects cellular functions, the differentially accumulated proteins were analyzed through protein-protein interaction networks. The different interactions that occur among proteins are at the core of cell processing, and their systematic characterization helps to contextualize these proteins in the biological molecular system [28]. This fact can be verified in the Santa Clara genotype for proteins related to the photosynthetic process as well as between metabolic and energy proteins. In the protein interaction network of BGH-2127, interactions occurred among proteins related to the photosynthetic process and also between energy proteins and metabolism. Another interaction network occurred between the protein $\mathrm{N}$-terminal domain rich in leucine repetition (spot 84 ) with the protein ribulose 3-phosphate epimerase (spot 53), which in turn interacted with ribulosebiphosphate carboxylase small chain proteins (spot 5) and ribolosyphosphate carboxylase small chain $3 \mathrm{~B}$ (spot 275). The interactions of the ribulose 3-phosphette epimerase (spot 53) protein with distinct functional groups are of great interest since, in general, each "protein community" represents a distinct cellular process. Thus a protein that is a member of more than one "community" participates in several processes and can be considered to be one of the connections among them [70]. The connectivity of proteins observed in this biological network indicates the occurrence of important physiological changes in the functional regulation of the cellular mechanisms involved in the resistance of BGH-2127 to late blight.

\section{Conclusion}

Proteins related to oxidative stress (PR-9) and thaumatin-like family (PR-5) play 
an important role in the $\mathrm{BGH}-2127$-access defense mechanism against resistant to tomato late blight.

\section{Acknowledgements}

To the Laboratory of Proteomics and Protein Biochemistry (LPBP) and to the Biomolecules of Analysis of Center (NUBIOMOL) at the Federal University of Viçosa for providing support for the accomplishment of the experiment. This work was supported by the Coordination of Improvement of Higher Education Personnel (CAPES), the National Council for Scientific and Technological Development (CNPq), the State of Minas Gerais Research Foundation (FAPEMIG), the Studies and Projects Funding Fund (FINEP) and National System of Laboratories in Nanotechnologies (SisNANO)/Ministry of Science, Technology and Information (MCTI).

\section{References}

[1] Nowicki, M., Foolad, M.R., Nowakowska, M. and Kozik, E.U. (2012) Potato and Tomato Late Blight Caused by Phytophthora infestans: An Overview of Pathology and Resistance Breeding. Plant Disease, 96, 4-17. https://doi.org/10.1094/PDIS-05-11-0458

[2] Foolad, M.R., Sullenberger, M.T., Ohlson, E.W. and Gigino, B.K. (2014) Response of Accessions within Tomato Wild Species, Solanum pimpinellifolium to Late Blight. Plant Breeding, 133, 401-411. https://doi.org/10.1111/pbr.12172

[3] Hu, C.H., Perez, F.G., Donahoo, R., Mcleod, A., Myers, K., Ivors, K., Secor, G., Roberts, P.D., Deahl, K.L., Fry, W.E. and Ristaino, J.B. (2012) Recent Genotypes of Phytophthora infestans in the Eastern United States Reveal Clonal Populations and Reappearance of Mefenoxam Sensitivity. Plant Disease, 96, 1323-1330. https://doi.org/10.1094/PDIS-03-11-0156-RE

[4] Mundt, C.C. (2014) Durable Resistance: A key to Sustainable Management of Pathogens and Pests. Infection, Genetics and Evolution, 27, 446-455.

https://doi.org/10.1016/j.meegid.2014.01.011

[5] Abreu, F.B., Silva, D.J.H., Cruz, C.D. and Mizubuti, E.S.G. (2008) Inheritance of Resistance to Phytophthora infestans (Peronosporales, Pythiaceae) in a New Source of Resistance in Tomato (Solanum sp. (Formely Lycopersicon sp.), Solanales, Solanaceae). Genetics and Molecular Biology, 31, 493-497. https://doi.org/10.1590/S1415-47572008000300016

[6] Adalid, A.M., Roselló, S., Valcárcel, M. and Nuez, F. (2012) Analysis of the genetic Control of $\beta$-Carotene and L-Ascorbic Acid Accumulation in an Orange-Brownish Wild Cherry Tomato Accession. Euphytica, 184, 251-263. https://doi.org/10.1007/s10681-011-0584-X

[7] Laurindo, B.S., Laurindo, R.D.F., Nick, C., Carneiro, P.C.S., Mizubuti, E.S.G. and Silva, D.J.H. (2016) Potencial de hibridação entre acessos de tomateiro para pré melhoramento quanto à resistência à requeima. Pesquisa Agropecuária Brasileira, 51, 27-34. https://doi.org/10.1590/S0100-204X2016000100004

[8] Michelmore, R.W., Christopoulou, M. and Caldwell, K.S. (2013) Impacts of resistance Gene Genetics, Function, and Evolution on a Durable Future. Annual Review of Phytopathology, 51, 291-319.

https://doi.org/10.1146/annurev-phyto-082712-102334 
[9] Almagro, L., Gómez-Ros, L.V., Belchi-Navarro, S., Bru, R., Rosbarcelo, A. and Pedreño, M.A. (2009) Class III Peroxidases in Plant Defence Reactions. Journal of EXperimental Botany, 60, 377-390. https://doi.org/10.1093/jxb/ern277

[10] van Loon, L.C., Rep, M. and Pieterse, C.M.J. (2006) Significance of Inducible Defense-Related Proteins in Infected Plants. Annual Review of Phytopathology, 44, 135-162. https://doi.org/10.1146/annurev.phyto.44.070505.143425

[11] Ma, L., Houterman, P.M., Gawehns, F., Cao, L., Sillo, F., Richter, H., Clavijo-Ortiz, M.J., Schmidt, S.M., Boeren, S., Vervoort, J., Cornelissen, B.J.C., Rep, M. and Cornelissen, B.J. (2015) The $A V R 2-S I X 5$ Gene Pair Is Required to Activate I-2-Mediated Immunity in Tomato. New Phytology, 208, 507-518. https://doi.org/10.1111/nph.13455

[12] Jung, J., Kim, H.J., Lee, J.M., Oh, C.S., Lee, H.J. and Yeam, I. (2015) Gene-Based Molecular Marker System for Multiple Disease Resistances in Tomato against Tomato Yellow Leaf Curl Virus, Late Blight, and Verticillium Wilt. Euphytica, 205, 599-613. https://doi.org/10.1007/s10681-015-1442-Z

[13] Zuluaga, A.P., Vega-Arreguín, J.C., Fei, Z., Matas, A.J., Patev, S., Fry, W.E. and Rose, J.K. (2016) Analysis of the Tomato Leaf Transcriptome during Successive Hemibiotrophic Stages of a Compatible Interaction with the Oomycete Pathogen Phytophthora infestans. Molecular Plant Pathololy, 17, $42-54$. https://doi.org/10.1111/mpp.12260

[14] Gonzalez-Fernandez, R. and Jorrin-Novo, J.V. (2011) Contribution of Proteomics to the Study of Plant Pathogenic Fungi. Journal of Proteome Research, 11, 3-16. https://doi.org/10.1021/pr200873p

[15] Vitale, A., Rocco, M., Arena, S., Giuffrida, F., Cassaniti, C., Scaloni, A., Lomaglio, T., Guarnaccia, V., Polizzi, G., Marra, M. and Leonardi, C. (2014) Tomato Susceptibility to Fusarium crown and Root Rot: Effect of Grafting Combination and Proteomic Analysis of Tolerance Expression in the Rootstock. Plant Physiology and Biochemistry, 83, 207-216. https://doi.org/10.1016/j.plaphy.2014.08.006

[16] Ghosh, S., Narula, K., Sinha, A., Ghosh, R., Jawa, P., Chakraborty, N. and Chakraborty, S. (2016) Proteometabolomic Analysis of Transgenic Tomato Overexpressing Oxalate Decarboxylase Uncovers Novel Proteins Potentially Involved in Defense Mechanism against Sclerotinia. Journal of Proteomics, 143, 242-253. https://doi.org/10.1016/j.jprot.2016.04.047

[17] Carmo, L.S., Murad, A.M., Resende, R.O., Boiteux, L.S., Ribeiro, S.G., Jorrín-Novo, J.V. and Mehta, A. (2017) Plant Responses to Tomato Chlorotic Mottle Virus: Proteomic View of the Resistance Mechanisms to a Bipartite Begomovirus in Tomato. Journal of Proteomics, 151, 284-292. https://doi.org/10.1016/j.jprot.2016.07.018

[18] Nowicki, M., Kozik, E.U. and Foolad, M.R. (2013) Late Blight of Tomato. In: Varshney, R.K. and Tuberosa, R., Eds., Translational Genomics for Crop Breeding: Biotic Stress, Vol. 1, John Wiley \& Sons Ltd., Chichester, 241-265. https://doi.org/10.1002/9781118728475.ch13

[19] Shen, S., Matsubae, M., Takao, T., Tanaka, N. and Komatsu, S. (2002) A Proteomic Analysis of Leaf Sheaths from Rice. Journal of Biochemistry, 132, 613-620. https://doi.org/10.1093/oxfordjournals.jbchem.a003264

[20] Bradford, M.M. (1976) A Rapid and Sensitive Method for the Quantitation of Microgram Quantities of Protein Utilizing the Principle of Protein-Dye Binding. Analytical Biochemistry, 7, 248-254. https://doi.org/10.1016/0003-2697(76)90527-3

[21] GE, Healthcare (2010) 2-D Electrophoresis Using Immobilized pH Gradients- 
Principles and Methods. Code No. 80-6429-60.

[22] Laemmli, U.K. (1970) Cleavage of Structural Proteins during the Assembly of the Head of Bacteriophage T4. Nature, 227, 680-685. https://doi.org/10.1038/227680a0

[23] Shevchenko, A., Tomas, H., Havlis, J., Olsen, J.V. and Mann, M. (2006) In-Gel Digestion for Mass Spectrometric Characterization of Proteins and Proteomes. Nature Protocols, 1, 2856-2860. https://doi.org/10.1038/nprot.2006.468

[24] Altschul, S.F., Gish, W., Miller, W., Myers, E.W. and Lipman, D.J. (1990) Basic Local Alignment Search Tool. Journal of Molecular Biology, 215, 403-410. https://doi.org/10.1016/S0022-2836(05)80360-2

[25] Keller, A., Nesvizhskii, A.I., Kolker, E. and Aebersold, R. (2002) Empirical Statistical Model to Estimate the Accuracy of Peptide Identifications Made by MS/MS and Database Search. Analytical Chemistry, 74, 5383-5392. https://doi.org/10.1021/ac025747h

[26] Nesvizhskii, A.I., Keller, A., Kolker, E. and Abersold, R.A. (2003) Statistical Model for Identifying Proteins by Tandem Mass Spectrometry. Analytical Chemistry, 75, 4646-4658. https://doi.org/10.1021/ac0341261

[27] Thimm, O., Bläsing, O., Gibon, Y., Nagel, A., Meyer, S., Krüger, P., Selbig, J., Muller, L.A., Rhee, S.Y. and Stitt, M. (2004) MAPMAN: A User-Driven Tool to Display Genomics Data Sets onto Diagrams of Metabolic Pathways and Other Biological Processes. The Plant Journal, 37, 914-939. https://doi.org/10.1111/j.1365-313X.2004.02016.x

[28] Szklarczyk, D., Franceschini, A., Wyder, S., Forslund, K., Heller, D., Huerta-Cepas, J., et al. (2014) Microbial Peptidyl-Prolyl cis/trans Isomerases (PPlases): Virulence Factors and Potential Alternative Drug Targets. Microbiology and Molecular Biology Reviews, 78, 544-571.

[29] Li, J. and Luan, Y. (2014) Molecular Cloning and Characterization of a Pathogen-Induced WRKY Transcription Factor Gene from Late Blight Resistant Tomato Varieties Solanum pimpinellifolium L3708. Physiological and Molecular Plant Pathology, 87, 25-31. https://doi.org/10.1016/j.pmpp.2014.05.004

[30] Pfaffl, M.W., Horgan, G.W. and Dempfle, L. (2002) Relative Expression Software Tool $\left(\right.$ REST $\left.^{\odot}\right)$ for Group-Wise Comparison and Statistical Analysis of relative Expression Results in Real-Time PCR. Nucleic Acids Research, 30, e36. https://doi.org/10.1093/nar/30.9.e36

[31] Kamoun, S., Furzer, O., Jones, J.D.G., Judelson, H.S., Ali, G.S., Dalio, R.J.D., Roy, S.G., Schena, L., Zambounis, A., Panabières, F., Cahill, D., Ruocco, M., Figueiredo, A., Chen, X.R., Hulvey, J., Stam, R., Lamour, K., Gijzen, M., Tyler, B.M., Grünwald, N.J., Mukhtar, M.S., Tomé, D.F.A., Tör, M., Ackerveken, G.V.D., McDowell, J., Daayf, F., Fry, W.E., Lindqvist-Kreuze, H., Meijer, H.J.G., Petre, B., Ristaino, J., Yoshida, K., Birch, P.R.J. and Govers, F. (2015) The Top 10 Oomycete Pathogens in Molecular Plant Pathology. Molecular Plant Pathology, 16, 413-434.

https://doi.org/10.1111/mpp.12190

[32] Ohlson, E.W. and Foolad, M.R. (2016) Genetic Analysis of Resistance to Tomato Late Blight in Solanum pimpinellifolium Accession PI 163245. Plant Breeding, 135, 391-398. https://doi.org/10.1111/pbr.12366

[33] Haggard, J.E., Johnson, E.B. and St. Clair, D.A. (2015) Multiple QTL for Horticultural Traits and Quantitative Resistance to Phytophthora infestans Linked on Solanum habrochaites Chromosome 11. G3: Genes, Genomes, Genetics, 5, 219-233. https://doi.org/10.1534/g3.114.014654

[34] Galmes, J., Conesa, M.A., Ochogavía, J., Perdomo, J.A., Francis, D.M., Ribas-Carbó, 
M., Savé, R., Flexas, J., Medrano, H. and Cifre, J. (2011) Physiological and Morphological Adaptations in Relation to Water Use Efficiency in Mediterranean Accessions of Solanum lycopersicum. Plant, Cell \& Environment, 34, 245-260.

https://doi.org/10.1111/j.1365-3040.2010.02239.x

[35] Wu, L., Han, Z., Wang, S., Wang, X., Sun, A., Zu, X. and Chen, Y. (2013) Comparative Proteomic Analysis of the Plant-Virus Interaction in Resistant and Susceptible Ecotypes of Maize Infected with Sugarcane mosaic virus. Journal of Proteomics, 89, 124-140. https://doi.org/10.1016/j.jprot.2013.06.005

[36] Liu, J., Qian, C. and Cao, X. (2016) Post-Translational Modification Control of Innate Immunity. Immunity, 45, 15-30. https://doi.org/10.1016/j.immuni.2016.06.020

[37] Cipriano, A.K., Gondim, D.M., Vasconcelos, I.M., Martins, J.Á., Moura, A.A., Moreno, F.B., Monteiro-Moreira, A.C.O., Melo, J.G.O., Cardoso, J.E., Paiva, A.L.S. and Oliveira, J.T. (2015) Proteomic Analysis of Responsive Stem Proteins of Resistant and Susceptible Cashew Plants after Lasiodiplodia theobromae Infection. Journal of Proteomics, 113, 90-109. https://doi.org/10.1016/j.jprot.2014.09.022

[38] Swarbrick, P.J., Schulze-Lefert, P. and Scholes, J.D. (2006) Metabolic Consequences of Susceptibility and Resistance (Race-Specific and Broad-Spectrum) in Barley Leaves Challenged with Powdery Mildew. Plant, Cell \& Environment, 29, 1061-1076. https://doi.org/10.1111/j.1365-3040.2005.01472.x

[39] Berger, S., Sinha, A.K. and Roitsch, T. (2007) Plant physiology Meets Phytopathology: Plant Primary Metabolism and Plant-Pathogen Interactions. Journal of Experimental Botany, 58, 4019-4026. https://doi.org/10.1093/jxb/erm298

[40] Millar, A.H., Whelan, J., Soole, K.L. and Day, D.A. (2011) Organization and Regulation of Mitochondrial Respiration in Plants. Annual Review of Plant Biology, 62, 79-104. https://doi.org/10.1146/annurev-arplant-042110-103857

[41] Cao, Y., Tanaka, K., Nguyen, C.T. and Stacey, G. (2014) Extracellular ATP Is a Central Signaling Molecule in Plant Stress Responses. Current Opinion in Plant Biolo$g y$, 20, 82-87. https://doi.org/10.1016/j.pbi.2014.04.009

[42] Zaffagnini, M., Michelet, L., Sciabolini, C., Di Giacinto, N., Morisse, S., Marchand, C.H., Trost, P., Fermani, S. and Lemaire, S.D. (2014) High-Resolution Crystal Structure and Redox Properties of Chloroplastic Triosephosphate Isomerase from Chlamydomonas reinhardtii. Molecular Plant, 7, 101-120. https://doi.org/10.1093/mp/sst139

[43] Pang, Z., Srivastava, V., Liu, X. and Bulone, V. (2017) Quantitative Proteomics Links Metabolic Pathways to Specific Developmental Stages of the Plant-Pathogenic Oomycete Phytophthora capsici. Molecular Plant Pathology, 18, 378-390.

[44] Kangasjärvi, S., Tikkanen, M., Durian, G. and Aro, E.M. (2014) Photosynthetic Light Reactions-An Adjustable Hub in Basic Production and Plant Immunity Signaling. Plant Physiology and Biochemistry, 81, 128-134. https://doi.org/10.1016/j.plaphy.2013.12.004

[45] Scharte, J., Schön, H. and Weis, E. (2005) Photosynthesis and Carbohydrate Metabolism in Tobacco Leaves during an Incompatible Interaction with Phytophthora nicotianae. Plant, Cell \& Environment, 28, 1421-1435. https://doi.org/10.1111/j.1365-3040.2005.01380.x

[46] Gulen, H. and Eris, A. (2004) Effect of Heat Stress on Peroxidase Activity and Total Protein Content in Strawberry Plants. Plant Science, 166, 739-744. https://doi.org/10.1016/j.plantsci.2003.11.014

[47] Bolton, M.D. (2009) Primary Metabolism and Plant Defense-Fuel for the Fire. Molecular Plant-Microbe Interactions, 22, 487-497. 
https://doi.org/10.1094/MPMI-22-5-0487

[48] Garavaglia, B.S., Thomas, L., Gottig, N., Zimaro, T., Garofalo, C.G., Gehring, C. and Ottado, J. (2010) Shedding Light on the Role of Photosynthesis in Pathogen Colonization and Host Defense. Communicative \& Integrative Biology, 3, 382-384. https://doi.org/10.4161/cib.3.4.12029

[49] Valueva, T.A. and Mosolov, V.V. (2004) Role of Inhibitors of Proteolytic Enzymes in Plant Defense against Phytopathogenic Microorganisms. Biochemistry (Moscow), 69, 1305-1309. https://doi.org/10.1007/s10541-005-0015-5

[50] Lehmann, S., Serrano, M., L’Haridon, F., Tjamos, S.E. and Metraux, J.P. (2015) Reactive Oxygen Species and Plant Resistance to Fungal Pathogens. Phytochemistry, 112, 54-62. https://doi.org/10.1016/j.phytochem.2014.08.027

[51] Awad, J., Stotz, H.U., Fekete, A., Krischke, M., Engert, C., Havaux, M., Berger, S. and Mueller, M.J. (2015) 2-Cysteine Peroxiredoxins and Thylakoid Ascorbate Peroxidase Create a Water-Water Cycle That Is Essential to Protect the Photosynthetic Apparatus under High Light Stress Conditions. Plant Physiology, 167, 1592-1603. https://doi.org/10.1104/pp.114.255356

[52] Koua, D., Cerutti, L., Falquet, L., Sigrist, C.J., Theiler, G., Hulo, N. and Dunand, C. (2009) PeroxiBase: A Database with New Tools for Peroxidase Family Classification. Nucleic Acids Research, 37, D261-D266. https://doi.org/10.1093/nar/gkn680

[53] Karuppanapandian, T., Moon, J.C., Kim, C., Manoharan, K. and Kim, W. (2011) Reactive Oxygen Species in Plants: Their Generation, Signal Transduction, and Scavenging Mechanisms. Australian Journal of Crop Science, 5, 709-725.

[54] Petre, B., Major, I., Rouhier, N. and Duplessis, S. (2011) Genome-Wide Analysis of Eukaryote Thaumatin-Like Proteins (TLPs) with an Emphasis on Poplar. BMC Plant Biology, 11, 33. https://doi.org/10.1186/1471-2229-11-33

[55] Liu, J.J., Sturrock, R. and Ekramoddoullah, A.K. (2010) The Superfamily of Thaumatin-Like Proteins: Its Origin, Evolution, and Expression towards Biological Function. Plant Cell Reports, 29, 419-436. https://doi.org/10.1007/s00299-010-0826-8

[56] Thompson, C.E., Fernandes, C.L., De Souza, O.N., Salzano, F.M., Bonatto, S.L. and Freitas, L.B. (2006) Molecular Modeling of Pathogenesis-Related Proteins of Family 5. Cell Biochemistry and Biophysics, 44, 385-394. https://doi.org/10.1385/CBB:44:3:385

[57] Latijnhouwers, M., De Wit, P.J. and Govers, F. (2003) Oomycetes and Fungi: Similar Weaponry to Attack Plants. Trends in Microbiology, 11, 462-469. https://doi.org/10.1016/j.tim.2003.08.002

[58] Nair, R.A., Kiran, A.G., Sivakumar, K.C. and Thomas, G. (2010) Molecular Characterization of an Oomycete-Responsive PR-5 Protein Gene from Zingiber zerumbet. Plant Molecular Biology Reporter, 28, 128-135.

https://doi.org/10.1007/s11105-009-0132-1

[59] Acharya, K., Pal, A.K., Gulati, A., Kumar, S., Singh, A.K. and Ahuja, P.S. (2013) Overexpression of Camellia sinensis Thaumatin-Like Protein, CsTLP in Potato Confers Enhanced Resistance to Macrophomina phaseolina and Phytophthora infestans Infection. Molecular Biotechnology, 54, 609-622. https://doi.org/10.1007/s12033-012-9603-y

[60] Jamet, E., Albenne, C., Boudart, G., Irshad, M., Canut, H. and Pont-Lezica, R. (2008) Recent Advances in Plant Cell Wall Proteomics. Proteomics, 8, 893-908. https://doi.org/10.1002/pmic.200700938

[61] Gomes, M.T.R., Oliva, M.L., Lopes, M.T.P. and Salas, C.E. (2011) Plant Proteinases and Inhibitors: An Overview of Biological Function and Pharmacological Activity. 
Current Protein \& Peptide Science, 12, 417-436.

https://doi.org/10.2174/138920311796391089

[62] Liu, H., Wang, X., Zhang, H., Yang, Y., Ge, X. and Song, F.A. (2008) Rice Serine Carboxypeptidase-Like Gene OsBISCPL1 Is Involved in Regulation of Defense Responses against Biotic and Oxidative Stress. Gene, 420, 57-65.

https://doi.org/10.1016/j.gene.2008.05.006

[63] Ashikawa, I. (2012) Regions outside the Leucine-Rich Repeat Domain Determine the Distinct Resistance Specificities of the Rice Blast Resistance Genes Pik and Pik-m. Molecular Breeding, 30, 1531-1535. https://doi.org/10.1007/s11032-012-9732-9

[64] Qi, D. and Innes, R.W. (2013) Recent Advances in Plant NLR Structure, Function, Localization, and Signaling. Frontiers in Immunology, 4, 348.

[65] Zhang, C., Liu, L., Wang, X., Vossen, J., Li, G., Li, T., Zheng, Z., Gao, J., Guo, Y., Visser, R.G.F., Li, J., Bai, Y. and Du, Y. (2014) The Ph-3 Gene from Solanum pimpinellifolium Encodes CC-NBS-LRR Protein Conferring Resistance to Phytophthora infestans. Theoretical and Applied Genetics, 127, 1353-1364. https://doi.org/10.1007/s00122-014-2303-1

[66] Mazzucotelli, E., Mastrangelo, A.M., Crosatti, C., Guerra, D., Stanca, A.M. and Cattivelli, L. (2008) Abiotic Stress Response in Plants: When Post-Transcriptional and Post-Translational Regulations Control Transcription. Plant Science, 174, 420-431. https://doi.org/10.1016/j.plantsci.2008.02.005

[67] Jing, H., Yang, X., Zhang, J., Liu, X., Zheng, H., Dong, G., Nian, J., Feng, J., Xia, B., Quian, Q., Li, J. and Zuo, J.(2015) Peptidyl-Prolyl Isomerization Targets Rice Aux/IAAs for Proteasomal Degradation during Auxin Signalling. Nature Communications, 6, Article No. 7395. https://doi.org/10.1038/ncomms8395

[68] Kromina, K.A., Ignatov, A.N. and Abdeeva, I.A. (2008) Role of Peptidyl-Prolyl-cis/ trans-Isomerases in Pathologic Processes. Biochemistry(Moscow), Supplement Series A: Membrane and Cell Biology, 2, 195-202.

https://doi.org/10.1134/S199074780803001X

[69] Ünal, C.M. and Steinert, M. (2014) Microbial Peptidyl-Prolyl cis/trans Isomerases (PPIases): Virulence Factors and Potential Alternative Drug Targets. Microbiology and Molecular Biology Reviews, 78, 544-571. https://doi.org/10.1128/MMBR.00015-14

[70] Jonsson, P.F. and Bates, P.A. (2006) Global Topological Features of Cancer Proteins in the Human Interactome. Systematic Biology, 22, 2291-2297. https://doi.org/10.1093/bioinformatics/btl390 